\title{
PENGARUH PERILAKU BELAJAR, KECERDASAN EMOSIONAL DAN PEMBAHASAN HABLUMMINNANNAS TERHADAP KEPRIBADIAN AKADEMIK DI INSTITUT AGAMA ISLAM TAFAQQUH FIDDIN DUMAI
}

\author{
${ }^{1}$ WINDAYANI, ${ }^{2} \mathrm{KHAIRIL}$ ANWAR \\ ${ }^{1}$ Institut Agama Islam Tafaqquh Fiddin Dumai \\ ${ }^{2}$ Program Pascasarjana, UIN Sultan Syarif Kasim Riau \\ windayaniok@gmail.com
}

\begin{abstract}
Based on preliminary research results, it is found that students' academic personality data of Tafaqquh Fiddin Islamic Institution Dumai is low. The low level of students' academic personality is presumably due to the influence of learning behavior, emotional intelligence, and the understanding of hablumminnannas. Therefore, the purpose of this research is to analyze the influence of learning behavior, emotional intelligence, and understanding of student hablumminnannas at Tafaqquh Fiddin Islamic Religious Institute Dumai. This research is a quantitative research with the sample of 100 students. The data analysis uses multiple regression to answer the research hypothesis by using software SPSS version 21 and Eviews version 7. The results of this analysis show: The significance value of 0.000 which means the existence of a simultaneous positive influence between learning behavior, emotional intelligence, and hablumminnannas understanding of the academic personality, where $F=53.97 \%$ with $p<0.05$. The result of the influence of learning behavior, emotional intelligence, and understanding of hablumminnannasis equal to $63 \%$. Partially viewed as the highest variable affecting the academic personality is understanding hablumminnannas.
\end{abstract}

Keywords: learning behavior, emotional intelligence, hablumminannas understanding, academic personality.

\section{LATAR BELAKANG MASALAH}

Kepribadian Akademik yang dicapai seorang mahasiswa merupakan hasil interaksi dari berbagai faktor yang mempengaruhinya, baik dari dalam diri mahasiswa (faktor internal), maupun dari luar diri mahasiswa (faktor eksternal). Pengenalan terhadap faktor - faktor yang mempengaruhi kepribadian akademik diperlukan untuk memahami bagaimana perubahan dalam determinan tersebut berhubungan dengan perubahan prestasi, sehingga pada akhirnya 
Windayani, Khairil Anwar; Pengaruh Prilaku Belajar, Kecerdasan Emosional dan Pembahasan Hablumminnannas Terhadap Kepribadian Akademik Di Institut Agama Islam Tafaqquh Fiddin Dumai

menjadi rekomendasi bag pengambilan kebijakan dalam pendidikan. Menurut Hamalik (1983:139), salah satu faktor yang bersumber dari dalam diri sendiri adalah kebiasaan belajar, atau tepatnya perilaku belajar. Untuk menghasilkan lulusan yang berkualitas yang paham dan mampu mengaplikasikan ilmu pengetahuan yang telah didapatnya selama perkuliahan, serta mampu bersaing di dunia kerja, pihak perguruan tinggi harus mengetahui apa saja faktor faktor yang mempengaruhi seorang mahasiswa dalam memahami pelajaran yang diterimanya.

Belajar diperguruan tinggi merupakan pilihan strategis dalam mencapai tujuan individual seseorang. Semangat, cara belajar, dan sikap mahasiswa terhadap belajar sangat dipengaruhi oleh kesadaran akan adanya tujuan individual dan tujuan lembaga pendidikan yang jelas. Kuliah merupakan ajang untuk mengkonfirmasi pemahaman mahasiswa dalam proses belajar mandiri. Pengendalian proses belajar lebih penting daripada hasil atau nilai ujian. Kalau proses belajar dijalankan dengan baik, nilai merupakan konsekuensi logis dari proses tersebut. Kecerdasan merupakan ciri keunggulan manusia dalam memahami, memutuskan, dan mengantisipasi serta menghadapi sesuatu. Kecerdasan merupakan salah satu anugerah besar dari Allah SWT. Kepada manusia dan menjadikannya sebagai salah satu kelebihan manusia dibandingkan dengan makhluk lainnya. Karena dengan kecerdasannya, manusia dapat terus menerus mempertahankan dan meningkatkan kualitas hidupnya yang semakin kompleks, melalui proses berfikir dan belajar terus menerus.

Perilaku belajar tidak dirasakan sebagai beban, tetapi sebagi kebutuhan. Hal ini tercipta karena terus menerus dilakukan dengan bimbingan dan pengawasan serta keteladanan dalam semua aspek dan kreativitas pendidikan. Selain itu, terdapat kondisi dan situasi perkuliahan yang memang diciptakan untuk mendukung berlangsungnya kemunculan kreatifitas dan kegiatan - kegiatan lain dalam konteks pembelajaran. Menurut Thomas E. Odea (1996:21) Agama dapat mempengaruhi sikap praktis manusia terhadap berbagai aktivitas kehidupan sehari-hari, ia dipandang sebagai jalan hidup yang dipegang dan diwarisi turun-temurun oleh manusia. Agar hidup mereka menjadi damai, tertib dan tidak kacau, yang menjadi unsur agama ialah:

1. Pengakuan bahwa ada kekuatan gaib yang menguasai atau mempengaruhi kehidupan manusia.

2. Keyakinan bahwa keselamatan hidup manusia tergantung pada adanya hubungan baik antara manusia dengan kekuatan ghaib.

3. Sikap emosional pada hati manusia terhadap kekuatan gaib itu, seperti takut hormat, penuh harap, pasrah dan lainlain.

4. Tingkat laku tertentu yang dapat diamati, seperti shalat, doa, puasa, zakat, suka menolong, tidak korupsi dan lain sebagainya.

Unsur-unsur ini sejalan dengan pandangan Nur Cholis Madjid (2009:23) yang mengatakan bahwa orang yang beragama harus memiliki tiga hal yang dikenal dengan trilogy ajaran ilahi yakni 
Iman, Islam dan Ihsan. Islam (alIslam) tidak absah tanpa Iman (alIman), dan Iman tidak sempurna tanpa Ihsan(allhsan). Sebaliknya, Ihsan adalah mustahil tanpa Iman, danlman juga tidak mungkin tanpa inisial Islam. Iman, Islam dan Ihsan merupakan pilar/pokok (rukun) dalam beragama dan dipahami sebagai sebuah sistem ajaran demi tegaknya ajaran Islam. Antara Iman, Islam dan Ihsan, ketiganya tak bisa dipisahkan oleh manusia di dunia ini, kalau diibaratkan hubungan diantara ketiganya adalah seperti segitiga simetris, dimana sisi satu dan sisi lainya berkaitan erat. Segitiga tersebut tidak pernah terbentuk kalau ketiga sisinya tidak saling mengait.Jadi manusia yang bertaqwa harus bisa meraih dan menyeimbangkan antara Iman, Islam dan Ihsan.

\section{PERILAKU BELAJAR}

Menurut Muhibbin Syah (2006:68 ) Belajar merupakan suatu proses perubahan perilaku atau pribadi seseorang berdasarkan praktik atau pengalaman tertentu. Perubahan yang terjadi dapat berupa penambahan hal baru atau peningkatan pemahaman yang sudah ada. Akan tetapi bias juga proses belajar mereduksi hal negatif yang tidak dikehendaki manusia. Belajar dapat pula dipahami sebagai tahapan perubahan seluruh tingkah laku individu yang relatif menetap sebagai hasil pengalaman dan interaksi dengan lingkungan yang melibatkan proses kognitif. Dalam proses belajar di perguruan tinggi, mahasiswa mengalami perubahan perilaku dan bertambahnya pemahaman baru. Belajar wajib dilakukan mahasiswa dalam rangka untuk mencapai prestasi akademik yang memuaskan. Untuk mencapai hal tersebut maka perilaku belajarnya haruslah positif.

Menurut Deni Arisandi

dalam Jurnal (2016:27) Perilaku adalah semua kegiatan atau aktifitas manusia, baik yang dapat diamati langsung maupun yang tidak dapat diamati pihak luar". Perubahan perilaku dapat diciptakan dengan merubah peristiwa didalam lingkungan yang menyebabkan perilaku tersebut. Sehingga dapat disimpulkan bahwa perilaku belajar merupakan semua kegiatan atau aktifitas dalam rangka memperoleh hal, pemahaman, tingkah laku baru individu dalam mencapai suatu tujuan tertentu. Menurut Makmun (2007:158), belajar memiliki beberapa karakteristik dasar dapat diidentifikasi beberapa ciri perubahan yang merupakan perilaku belajar diantaranya: 1. Bahwa perubahan intensional, dalam arti pengalaman atau praktik atau latihan itu dengan sengaja dan disadari dilakukannya dan bukan secara kebetulan. 2.Bahwa perubahan itu positif, dalam arti sesuai seperti yang diharapkan (normatif) atau criteria keberhasilan (criteria of success) baik dipandang dari segi mahasiswa maupun dari guru (pengajar). 3. Bahwa perubahan itu efektif, dalam arti membawa pengaruh dan makna tertentu bagi pelajar itu relative tetap dan setiap saat diperlukan dapat direproduksi dan dipergunakan seperti dalam pemecahan masalah (problem solving), baik dalam ujian, ulangan, dan sebagainya maupun dalam penyesuaian diri dikehidupan seharihari dalam rangka mempertahankan kehidupannya.

Perilaku belajar merupakan kebiasaan belajar yang dilakukan secara berulang-ulang oleh individu sehingga menjadi otomatis atau berlangsung secara spontan. Yang 
Windayani, Khairil Anwar; Pengaruh Prilaku Belajar, Kecerdasan Emosional dan Pembahasan Hablumminnannas Terhadap Kepribadian Akademik Di Institut Agama Islam Tafaqquh Fiddin Dumai

termasuk dalam bentuk perilaku belajar adalah sebagai berikut: 1 . Kebiasaan mengikuti perkuliahan Kebiasaan mengikuti perkuliahan adalah kebiasaan yang dilakukan mahasiswa pada saat pelajaran sedang berlangsung. Mahasiswa yang mengikuti pelajaran dengan tertib dan penuh perhatian serta dicatat dengan baik akan memperoleh pengetahuan lebih banyak. Kebiasaan mengikuti pelajaran ini ditekankan pada kebiasaan memperhatikan penjelasan dosen, membuat catatan.meminta penjelasan atau bertanya, membuat tugas, dan penempatan posisi duduk selama perkuliahan. 2. Kegiatan Membaca Buku Kegiatan membaca buku merupakan keterampilan membaca yang paling penting untuk dikuasai mahasiswa. Kebiasaan membaca buku harus dibudidayakan agar pengetahuan mahasiswa dapat bertambah dan dapat meningkatkan pemahaman mahasiswa dalam mempelajari suatu pelajaran. 3 . Kunjungan ke Perpustakaan

Kunjungan ke perpustakaan merupakan kebiasaan mahasiswa mengunjungi perpustakaan untuk mencari referensi yang dibutuhkan agar dapat menambah wawasan dan pemahaman terhadap pelajaran. Walaupun pada dasarnya sumber bacaan bisa ditemukan dimanamana, namun tempat yang paling umum dan memiliki sumber yang paling lengkap adalah perpustakaan. 4. Kebiasaan menghadapi ujian Ujian merupakan hal yang dialami mahasiswa setelah melakukan proses pembelajaran. Dengan melakukan ujian, maka dapat diketahui efektifitas proses pembelajaran yang telah dilakukan.

Adapun Ciri - cirri khusus yang menjadi karakteristik perilaku belajar adalah : 1. Perubahan
Intensional. Perubahan yang terjadi dalam proses belajar berkat pengalaman atau praktik yang dilakukan dengan sengaja dan disadari. Karakteristik ini maknanya adalah bahwa mahasiswa menyadari akan adanya perubahan yang dialami atau sekurangkurangnya ia merasakan adanya perubahan dalam dirinya, seperti penambahan pengetahuan, kebiasaan, sikap dan pandangan sesuatu dan keterampilan. 2. Perubahan Positif dan Aktif Perubahan yang terjadi karena proses belajar bersifat positif dan aktif. Perubahan yang bersifat positif maknanya baik, bermanfaat serta sesuai harapan. Hal ini juga bermakna bahwa perubahan tersebut senantiasa merupakan penambahan, yakni diperolehnya sesuatu yang relatif baru ( misalnya pemahaman dan keterampilan baru ) yang lebih baik dari apa yang telah ada sebelumnya. Perubahan bersifat aktif artinya tidak terjadi dengan sendirinya seperti karena proses pematangan. 3. Perubahan Efektif dan Fungsional. Perubahan yang timbul karena proses belajar bersifat efektif, yakni berdaya guna. Artinya, perubahan tersebut membawa pengaruh, makna dan manfaat tertentu bagi orang atau individu yang belajar. Perubahan yang bersifat fungsional juga bermakna bahwa ia relatif menetap dan setiap saat apabila dibutuhkan, perubahan tersebut dapat direduksi dan dimanfaatkan. Perubahan fungsional dapat diharapkan memberi manfaat yang luas.

Menurut Muhibbin Syah perwujudan perilaku belajar biasanya lebih sering tampak dalam perubahan - perubahan sebagai berikut : 1. Kebiasaan Setiap individu yang telah mengalami proses belajar, kebiasaan - 
Al-Fikra: Jurnal IImiah Keislaman, Vol. 16, No. 2,Juli - Desember, 2017 (269 304 )

kebiasaannya akan tampak berubah. Kebiasaan itu timbul karena proses penyusunan kecendrungan respon dengan menggunakan stimulus yang berulang - ulang. Dalam proses belajar, pembiasaan juga meliputi pengurangan perilaku yang tidak diperlakukan. Karena proses pengurangan inilah muncul suatu pola bertingkah laku yang relatif menetap dan otomatis. 2. Keterampilan adalah kegiatan yang berhubungan dengan urat - urat syaraf dan otot - otot yang lazimnya tampak dalam kegiatan jasmaniah seperti menulis, mengetik, olahraga dan sebagainya. Meskipun sifatnya motorik, tetapi keterampilan itu memerlukan koordinasi gerak yang diteliti dan kesadaran yang tinggi. Menurut Rebber yang diikuti Tohirin, keterampilan adalah kemampuan melakukan pola - pola tingkah laku yang kompleks dan tersusun rapi secara mulus dan sesuai dengan keadaan untuk mencapai hasil tertentu. Keterampilan bukan hanya meliputi gerakan motorik saja, melainkan juga pengejewantahan fungsi mental yang bersifat kognitif. 3. Kognitif Menurut Muhibbin Syah yang dikutip Tohirin, pengamatan artinya proses menerima, menafsirkan dan memberi arti rangsangan yang masuk melalui indera - indera seperti mata dan telinga. Berkat pengalaman belajar, seorang siswa akan mampu mencapai pengamatan yang benar objektif sebelum memperoleh pengertian. Pengamatan yang salah akan mengakibatkan timbulnya pengertian yang salah pula.4. Berpikir Asosiatif dan Daya Ingat Berpikir asosiatif adalah berpikir dengan cara mengasosiasikan sesuatu dengan yang lainnya. Berpikir asosiatif itu merupakan proses pembentukan hubungan antara rangsangan dengan respon.
Kemampuan mahasiswa untuk melakukan hubungan asosiatif yang benar amat dipengaruhi oleh tingkat pengertian atau pengetahuan yang diperoleh dari hasil belajar. Sedangkan daya ingat itu merupakan perwujudan belajar, sebab merupakan unsur pokok dalam berpikir asosiatif. Jadi, mahasiswa yang telah mengalami proses belajar akan ditandai dengan bertambahnya simpanan materi (pengetahuan dan pengertian) dalam memori, serta meningkatnya kemampuan menghubungkan materi tersebut dengan situasi atau stimulus yang sedang ia hadapi.

Berpikir Rasional dan Kritis Berpikir rasional dan kritis adalah perwujudan perilaku belajar, terutama yang bertalian dengan pemecahan masalah ( problem solving). Umumnya, mahasiswa yang berpikir rasional akan menggunakan prinsip - prinsip dan dasar - dasar pengertian dalam menjawab pertanyaan. Dalam berpikir rasional, mahasiswa dituntut menggunakan logika (akal sehat) untuk menentukan sebab akibat, menganalisis, menarik kesimpulankesimpulan dan bahkan juga menciptakan hukum-hukum (kaedah teoritis) dan ramaln - ramalan. 6 . Sikap adalah pandangan atau kecendrungan mental. Pada prinsipnya sikap adalah kecendrungan individu untuk bertindak dengan cara tertentu. Perwujudan perilaku belajar mahasiswa akan ditandai dengan muculnya kecendrungan kecendrungan baru yang telah berubah (lebih maju dan lugas ) terhadap suatu objrk, tata nilai, peristiwa dan sebagainya. Inhibisi adalah upaya pengurangan atau pencegahan timbulnya suatu respon tertentu karena danya proses respon lain yang sedang berlangsung. 
Windayani, Khairil Anwar; Pengaruh Prilaku Belajar, Kecerdasan Emosional dan Pembahasan Hablumminnannas Terhadap Kepribadian Akademik Di Institut Agama Islam Tafaqquh Fiddin Dumai

Dalam kaitannya dengan belajar, inhibisi bermakna kesanggupan mahasiswa untuk mengurangi atau menghentikan tindakan yang tidak perlu, lalu memilih atau melakukan tindakan lainnya yang lebih baik ketika ia berinteraksi dengan lingkungannya. Apresiasi adalah gejala ranah afektif yang umumnya ditujukan pada karya - karya seni budaya seperti sastra, music, lukis dan drama. ingkah Laku Afektif Tingkah laku afektif adalah tingkah laku yang menyangkut keanekaragaman perasaan seperti takut, marah, sedih, gembira, kecewa, senang, benci dan was was. Tingkah laku seperti ini tidak terlepas dari pengalaman belajar. Oleh karena itu ia dianggap sebagai perwujudan perilaku belajar.

\section{KECERDASAN EMOSIONAL}

Kecerdasan emosional
pertama kali dipublikasikan pada
tahun 1995 oleh seorang dosen
psikologi, Daniel Goleman. Pada
awal kemunculannya, banyak
kalangan yang tertarik dan kemudian
terpengaruh dengan berbagai
pandangan dalam teori tersebut. Di
dalam sejumlah ulasan tentang
kecerdasan emosional,
dikemukakan kecerdasan emosional
jauh lebih penting dari pada
kecerdasan dan kemampuan
intelektual seseorang dalam
mempengaruhi kn hesuksesan
hidupnya. Salah satu hal yang
mendasari pandangan ini adalah
gejolak perasaan sangat
mempengaruhi proses berpikir.
Misalnya, saat individu sedang
marah, konsentrasinya mulai
terganggu dan kemudian
mempengaruhi proses pengambilan
keputusan. Kecerdasan
emosional jika secara tradisional
diartikan sebagai kemampuan

membaca, menulis, dan berhitung yang merupakan keterampilan kata dan angka yang menjadi fokus dipendidikan formal (sekolah). Kecerdasan Emosi atau Emotional Quotation (EQ) meliputi kemampuan mengungkapkan perasaan, kesadaran serta pemahaman tentang emosi dan kemampuan untuk mengatur dan mengendalikannya. Kecerdasan emosional adalah kemampuan untuk memotivasi diri sendiri dan bertahan menghadapi frustasi, mengendalikan dorongan hati dan tidak melebihlebihkan kesenangan, mengatur suasana hati dan menjaga agar beban stres tidak melumpuhkan kemampuan berpikir ( Goleman, 2004:45).

Selain menurut Goleman, banyak dari para ahli yang memiliki pengertian mereka sendiri-sendiri mengenai kecerdasan emosional, diantaranya : Stainer pada tahun 1997 dalam Utama ( 2009: 1) menjelaskan keceradasan emosi adalah suatu kemampuan yang dapat mengerti emosi diri sendiri dan orang lain, serta mengetahui bagaimana emosi diri sendiri terekspresikan untuk meningkatkan maksimal etis sebagai kekuatan pribadi. Patton pada tahun 1998 dalam Utama (2009: 1) mengemukakan kecerdasan emosi sebagai kemampuan untuk mengetahui emosi secara efektif guna mencapai tujuan dan membangun hubungan yang produktif dan dapat meraih keberhasilan. Bar-On pada tahun 2000 dalam Utama (2009:1) menyebutkan kecerdasan emosi aadalah suatu rangkaian emosi dan kemampuan - kemampuan yang mempengaruhi kemampuan seluruh individu untuk mengatasi masalah tuntutan lingkungan secara efektif. 
Al-Fikra: Jurnal IImiah Keislaman, Vol. 16, No. 2,Juli - Desember, 2017 (269 304 )

Menurut Goleman, (2003:1415) ada empat kemmapuan yang mendasar yang ada pada kecerdasan emosional yaitu : Kesadaran Diri (Self Awarenes). Kesadaran diri emosional : kemampuan untuk membaca dan memahami emosi-emosi dan juga mengenal pengaruhnya pada kinerja, hubungan, dan sebagainya. Penilaian diri secara akurat : penilaian realistis dari kekuatan dan kelemahan. Kepercayaan diri : perasaan yang kuat dan sensitif mengenai harga diri. Hal ini didukung oleh Manajemen diri (SelfManagement ) yang terdiri dari Kontrol diri : Kemampuan untuk menjaga agar emosi dan kata hati yang mengganggu tetap terkontrol. Kepantasan untuk dipercaya : sesuatu penunjukkan dari kejujuran dan integritas yang terus - menerus. Kesungguhan : kemampuan untuk mengatur diri sendiri dan tanggung jawab yang dimiliki. Kemampuan beradaptasi : kemampuan untuk menyesuaikan diri dengan situasi yang berubah dan mengatasi masalah. Orientasi kesuksesan : dorongan untuk mewujudkan standar kesempurnaan pribadi. Inisiatif : kesiapan untuk merebut kesempatan.

Kesadaran sosial (SelfAwarenes). Empati : kemampuan merasakan emosi orang lain, memahami cara pandang mereka, dan tertarik secara aktif terhadap keprihatinan mereka. Kesadaran berorganisasi : kemampuan untuk membaca arus dari kehidupan berorganisasi, membangun jaringan keputusan, dan menavigasikan public. Orientasi jasa : kemampuan untuk mengenali dan memnuhi kebutuhan konsumen. Kemampuan Sosial (social-skill). Kepemimpinan bervisi : kemampuan untuk mengambil tanggungjawab dan memberikan inspirasi dengan visi sebagai pendorong. Pengaruh : kemampuan untuk mempergunakan taktik persuasif. Mengembangkan orang lain : feedback kecendrungan untuk mendukung kemampuan orang lain melalui dan bimbingan. Komunikasi : kemmapuan untuk mendengarkan dan mengirimkan pesan jelas, meyakinkan dan baik. Perubahan Katalisator : keahlian dalam memprakarsai ide-ide baru dan memimpin orang ke arah yang baru. Manajemen konflik : kemampuan untuk mengurangi ketidaksetujuan dan menyusun resolusi. Membangun ikatan : keahlian mempererat dan menjaga jaringan hubungan. Kerja tim dan kolaborasi : kemampuan mempromosikan kerjasama dan membangun tim.

Kecerdasan emosional menurut goleman merupakan seperangkat kemampuan yang dimiliki oleh manusia seperti kemampuan untuk memotivasi diri sendiri, dan bertahan menghadapi frustasi, mengendalikan dorongan hati dan tidak melebih-lebihkan kesenangan, mengatur suasana hati dan menjaga agar beban stress tidak melumpuhkan kemampuan berpikir, berempati dan berdoa. Mereka yang memiliki kecerdasan emosional mampu untuk mengelola emosi yang dimilikinya dengan baik. Mereka ini tidak mengenal putus asa karena mereka memiliki kemampuan untuk memotivasi diri mereka. Mereka mampu mengelola emosi mereka dalam pergaulan, termasuk didalamnya rasa empati yang tinggi terhadap penderitaan orang lain.

$E Q$ dua kali lebih penting dari IQ. Sebelum EQ dikenal luas oleh masyarakat, banyak diantara kita menganggap bahwa IQ adalah segala-galanya. Keberhasilan seseorang diukur dan ditentukan 
Windayani, Khairil Anwar; Pengaruh Prilaku Belajar, Kecerdasan Emosional dan Pembahasan Hablumminnannas Terhadap Kepribadian Akademik Di Institut Agama Islam Tafaqquh Fiddin Dumai

oleh tingkat IQ yang dimilikinya. Anastasi dan Willerman menyatakan bahwa dalam setiap kegiatan yang menuntut prestasi, baik itu prestasi belajar, prestas kerja, olahraga, seni dan sebagainya, inteligensi memegang peranan yang sangat penting. Kita semua setuju bahwa mahasiswa yang memiliki IQ yang tinggi akan lebih mudah dalam menerima pelajaran dibandingkan dengan mahasiswa yang IQ nya rendah. Demikian pula dalam halnya dengan bidang kerja lainnya. Tetapi hal itu bukanlah satu-satunya kunci seseorang dalam meraih keberhasilan dalam kehidupannya. $\mathrm{Hal}$ itu juga dipengaruhi dalam hal mereka mengelola emosi, seseorang yang memiliki IQ yang sedang, namun mampu mengelola emosinya dengan baik akan lebih berhasil dengan orang yang ber IQ tinggi namun tidak mampu mengelola emosinya dengan baik.

Mahasiswa yang ber IQ sedang namun mampu mengelola emosinya dengan baik, akan lebih berhasil dalam belajar dibandingkan dengan mahasiswa yang ber IQ tinggi tetapi tidak mampu mengelola emosinya. Mereka cenderung egois dan mau menang sendiri dan kurang memiliki rasa sosial. Hal tersebut menunjukkan kepada kita bahwa kecerdasan emosional yang dimiliki seseorang, dua kali lebih penting daripada kecerdasan intelektual. Kecerdasan emosi dapat menempatkan emosi seseorang pada porsi yang tepat, memilah kepuasan dan mengatur suasana hati. Koordinasi suasana hati adalah inti dari hubungan sosial yang baik, Apabila seseorang pandai menyesuaikan diri dengan suasana individu orang lain atau dapat berempati, orang tersebut akan memiliki tingkat emosionalitas yang baik dan akan lebih mudah menyesuaikan diri dalam pergaulan sosial dan lingkungannya.

Mayer dan Saloevay (Makmun Mubayidh 2006: 15) mendefenisikan bahwa:

"Kecerdasan emosi sebagai suatu kecerdasan sosial yang berkaitan dengan kemampuan individu dalam memantau baik emosi dirinya maupun emosi orang lain, dan juga kemampuannya dalam membedakan emosi dirinya dan emosi orang lain, dimana kemampuan ini digunakan untuk mengarahkan pola piker dan perilakunya ". Kecerdasan emosinal tidak hanya befungsi untuk mengendalikan diri, tetapi lebih dari itu juga, mencerminkan mengelola ide, konsep, karya atau produk sehingga hal itu menjadi minat orang banyak (Suharsono, 2004:120) Kecerdasan emosional bekerja secara sinergis dengan keterampilan kognitif mereka dengan potensi maksimum. Dalam Alquran kecerdasan emosi adalah suatu usaha seseorang untuk dapat mengelola emosi dan menahan hawa nafsunya dengan mengendalikan perasaan diri, mengatur diri, mampu melakukan interaksi sosial pada waktu dan kondisi tertentu. Hal ini sesuai dengan ajaran Islam bahwa Allah SWT, memerintahkan kita untuk bisa menguasai emosi, mengkontrol dan mengendalikannya.

\section{Kecerdasan Emosional dalam perspektif Islam.}

Alquran adalah kitab suci yang merupakan sumber utama ajaran Islam dan menjadi petunjuk kehidupan umat manusia yang diturunkan Allah kepada Nabi Muhammad SAW sebagai salah satu rahmat yang tidak ada duanya dalam semesta ini. Selain itu Alquran dengan banyak 
Al-Fikra: Jurnal IImiah Keislaman, Vol. 16, No. 2,Juli - Desember, 2017 (269 304 )

mengungkap tentang aspek-aspek psikologis manusia termasuk aspek kecerdasan emosional. Dalam perspektif Islam kecerdasan emosional yang dianjurkan adalah seseorang dapat mengelola emosi dan menahan hawa nafsu dengan cara mengendalikan perasaan, dalam Firman Allah SWT bahwasanya dalam mengelola emosi manusia hendaknya dapat menyadari perbuatannya. Dalam Surat As-shaffat : 102.

"Maka tatkala anak itu sampai (pada umur sanggup) berusaha bersama-sama Ibrahim, Ibrahim berkata :" Hai anakku, sesunggunya aku melihat dalam mimpi bahwa aku menyembelihmu. Maka fikirkanlah pendapatmu!". la menjawab "Hai bapakku, kerjakanlah apa yang diperintahkan kepadamu; Insyaallah kamu akan mendapatiku termasuk orang-orang yang sabar". Dalam Islam seseorang mengelola emosi dengan cara mengekpresikannya dalam bentuk sabar dalam menghadapi masalah, yang mana dengan bersabar seseorang akan menyadari bahwa dengan bersabar seseorang akan lebih ikhlas terhadap masalah yang sedang dihadapinya. Karena apapun yang ada di dunia ini akan kembali kepada Allah, maka seseorang hendaknya bersabar dalam menhadapi masalahnya. Seperti dijelakan dalam alquran bahwa orang yang bersabar dengan apa yang dihadapinya sekarang kemungkinan di masa yang akan datang mendapatkan hasil dari kesabarannya. Disamping itu seseorang memiliki kecerdasan pada dimensi emosional yakni mampu menguasai situasi yang penuh dengan tantangan yang biasa menimbulkan ketegangan dan kecemasan. Pengendalian emosi atau tidak adanya tindakan agresi terhadap orang lain yang disebabkan oleh emosi yang berlebihan serta selalu tenang akan menciptakan harmonitas dalam interaksi.

Adapun Faktor - faktor yang mempengaruhi Kecerdasan Emosional Goleman (1997) menjelaskan bahwa ada beberapa faktor yang mempengaruhi kecerdasan emosi individu yaitu: (a) Lingkungan keluarga. Kehidupan keluarga merupakan sekolah pertama dalam mempelajari emosi. Kecerdasan emosi dapat diajarkan pada saat masih bayi melalui ekspresi. Peristiwa emosional yang terjadi pada masa anak-anak akan melekat dan menetap secara permanen hingga dewasa. Kehidupan emosional yang dipupuk dalam keluarga sangat berguna bagi anak kelak dikemudian hari. (b) Lingkungan non keluarga. Hal ini yang terkait adalah lingkungan masyarakat dan pendidikan. Kecerdasan emosi ini berkembang sejalan dengan perkembangan fisik dan mental anak. Pembelajaran ini biasanya ditujukan dalam suatu aktivitas bermain peran sebagai seseorang diluar dirinya dengan emosi yang menyertai keadaan orang lain (Goleman, 1997).

Menurut Le Dove (Goleman, 1997) bahwa faktor-faktor yang mempengaruhi kecerdasan emosi antara lain: (a) Fisik. Secara fisik bagian yang paling menentukan atau paling berpengaruh terhadap kecerdasan emosi seseorang adalah anatomi saraf emosinya. Bagian otak yang digunakan untuk berfikir yaitu konteks (kadang kadang disebut juga neo konteks). Sebagai bagian yang berada dibagian otak 
yang mengurusi emosi yaitu system limbic, tetapi sesungguhnya antara kedua bagian inilah yang menentukan kecerdasan emosi seseorang. (1) Konteks. Bagian ini berupa bagian berlipat-lipat kira-kira 3 milimeter yang membungkus hemisfer serebral dalam otak. Konteks berperan penting dalam memahami sesuatu secara mendalam, menganalisis mengapa mengalami perasaan tertentu dan selanjutnya berbuat sesuatu untuk mengatasinya. Konteks khusus lobus prefrontal, dapat bertindak sebagai saklar peredam yang memberi arti terhadap situasi emosi sebelum berbuat sesuatu.

System limbic. Bagian ini sering disebut sebagai emosi otak yang letaknya jauh didalam hemisfer otak besar dan terutama bertanggung jawab atas pengaturan emosi dan implus. Sistem limbic meliputi hippocampus, tempat berlangsungnya proses pembelajaran emosi dan tempat disimpannya emosi. Selain itu ada amygdala yang dipandang sebagai pusat pengendalian emosi pada otak. (b) Psikis. Kecerdasan emosi selain dipengaruhi oleh kepribadian individu, juga dapat dipupuk dan diperkuat dalam diri individu.

Berdasarkan uraian tersebut dapat disimpulkan bahwa terdapat dua faktor yang dapat mempengaruhi kecerdasan emosi seseorang yaitu secara fisik dan psikis. Secara fisik terletak di bagian otak yaitu konteks dan sistem limbic, secara psikis meliputi lingkungan keluarga dan lingkungan non keluarga. Menurut Dinkmeyer (1965) faktor-faktor yang mempengaruhi kecerdasan emosi anak adalah faktor kondisi fisik dan kesehatan, tingkat intelegensi, lingkungan sosial, dan keluarga. Anak yang memiliki kesehatan yang kurang baik dan sering lelah cenderung menunjukkan reaksi emosional yang berlebihan. Anak yang dibesarkan dalam keluarga yang menerapkan disiplin yang berlebihan cenderung lebih emosional. Pola asuh orang tua berpengaruh terhadap kecerdasan emosi anak dimana anak yang dimanja, diabaikan atau dikontrol dengan ketat (overprotective) dalam keluarga cenderung menunjukkan reaksi emosional yang negatif (Dinkmeyer, 1965).

Dari faktor gen dan lingkungan tersebut kesempatan belajar merupakan faktor yang lebih penting. Karena belajar merupakan sesuatu yang positif dan sekaligus merupakan tindakan preventif. Maksudnya adalah bahwa apabila reaksi emosional yang tidak diinginkan dipelajari, kemudian membaur kedalam pola emosi anak, akan semakin sulit mengubahnya dengan bertambah usia anak, bahkan reaksi emosional tersebut akan tertanam kukuh pada masa dewasa dan untuk mengubahnya diperlukan bantuan ahli (soelaeman:2008). Menurut Goleman (Nggermanto, 2002), kecerdasan emosi dapat dikembangkan, lebih menantang, dan lebih prospek dibandingkan kecerdasan akademik sebab kecerdasan emosi memberi kontribusi lebih besar bagi kesuksesan seseorang. Menurut Agustian (2007) faktor-faktor yang berpengaruh dalam peningkatan kecerdasan emosi yaitu:

\section{PENTINGNYA MENINGKATKAN KECERDASAN EMOSIONAL}

Kecerdasan emosional (EQ) lebih berfokus pada membangun hubungan harmonis dan selaras antar manusia secara horizontal 
Al-Fikra: Jurnal IImiah Keislaman, Vol. 16, No. 2,Juli - Desember, 2017 (269 304 )

sehingga kecerdasan intelegensi pasti bermanfaat. Kecerdasan emosional dapat ditunjukkan melalui kemampuan seseoarang untuk menyadari apa yang dia dan orang lain rasakan. Sehingga itu, peserta didik memiliki tingkat kecerdasan emosional yang lebih baik cenderung dapat lebih terampil dalam menenangkan dirinya dengan cepat, jarang tertular penyakit, lebih terampil dalam memusatkan perhatian, lebih cakap dalam memahami orang lain dan untuk kerja akademis di sekolah menjadi lebih baik.

Keterampilan dasar kecerdasan emosional tidak dapat dimiliki secara tiba-tiba, tetapi membutuhkan proses dalam mempelajarinya, dan lingkungan yang membentuk kecerdasan emosional tersebut besar pengaruhnya. Dan ada beberapa cara yang dapat dilakukan untuk mengembangkan kecerdasan emosional dalam pembelajaran, yakni: 1). Menyediakan lingkungan yang kondusif; 2). Menciptakan iklim pembelajaran yang demokratis; 3). Mengembangkan sikap empati, dan merasakan apa yang sedang dirasakan peserta didik; 4). Membantu peserta didik menemukan solusi dalam setiap masalah yang dihadapinya; 5). Melibatkan peserta didik secara optimal dalam pembelajaran, baik secara fisik, sosial, maupun emosional; 6). Merespon setiap perilaku peserta didik secara positif, dan menghindari respon negatif; 7). Menjadi teladan dalam menegakkan aturan dan disiplin dalam pembelajaran; dan 8). Memberi kebebasan berfikir kreatif serta partisipasi secara aktif.

Semua hal tersebut

memungkinkan peserta didik mengembangkan seluruh potensi kecerdasannya secara optimal. Dari proses belajar mengajar di sekolah sering ditemukan peserta didik yang tidak dapat meraih prestasi belajar yang setara dengan kemampuan intelegensinya. Ada peserta didik yang mempunyai kemampuan intelegensi tinggi, tetapi memperoleh prestasi belajar yang relatif rendah. Dan ada pula peserta didik yang meski kemampuan intelegensinya relatif rendah, namun dapat meraih prestasi belajar yang relatif tinggi. Itu sebabnya taraf intelegensi bukan merupakan satu-satunya faktor yang menentukan keberhasilan.

Menurut

Goleman

(2000:44) kecerdasan intelektual (IQ) hanya menyumbang $20 \%$ bagi kesuksesan sedangkan $80 \%$ adalah sumbangan faktor kekuatankekuatan lain, di antaranya adalah kecerdasan emosional atau Emotional Quotient (EQ), yakni kemampuan memotivasi diri sendiri, mengatasi frustasi, mengontrol desakan hati, mengatur suasana hati (mood), berempati, serta kemampuan bekerja sama. E.Mulyasa (2006:162) menyatakan, kecerdasan emosional dapat menjadikan peserta didik memiliki sikap: 1). Jujur, disiplin, dan tulus pada diri sendiri, membangun kekuatan dan kesadaran diri, mendengarkan suara hati, hormat dan tanggung jawab; 2). Memantapkan diri, maju terus, ulet, dan membangun inspirasi secara berkesinambungan; 3). Membangun watak dan kewibawaan,meningkatkan potensi, dan mengintegrasi tujuan belajar ke dalam tujuan hidupnya; 4). Memanfaatkan peluang dan menciptakan masa depan yang lebih cerah (Sijabat: 2012). Sehingga dari sini, kecerdasan emosional (EQ) bukan merupakan lawan kecerdasan intelegensi (IQ), namun keduanya 
berinteraksi secara dinamis. Sebab, pada kenyataannya perlu diakui, bahwa kecerdasan emosional memiliki peran yang sangat penting untuk mencapai kesuksesan di sekolah maupun di lingkungan masyarakat.

\section{Kiat-kiat dalam meningkatkan kecerdasan emosional}

Menurut Mudrika nafis dalam membaca kepribadian (2011) Untuk meningkatkan kecerdasan emosional dibutuhkan kiat-kiat agar mempermudah dan memaksimalkan peningkatan tersebut, diantaranya sebagai berikut : Mengenali emosi diri. Keterampilan ini meliputi kemampuan anda untuk mengidentifikasi apa yang sesungguhnya anda rasakan. Setiap kali suatu emosi tertentu muncul dalam pikiran, Anda harus dapat menangkap pesan apa yang ingin disampaikan. Berikut adalah beberapa contoh pesan dari emosi: takut, sakit hati, marah, frustasi, kecewa, rasa bersalah, kesepian. Berikutnya Melepaskan emosi negative . Keterampilan ini berkaitan dengan kemampuan anda untuk memahami dampak dari emosi negatif terhadap diri anda. Sebagai contoh keinginan untuk memperbaiki situasi ataupun memenuhi target pekerjaan yang membuat Anda mudah marah ataupun frustasi seringkali justru merusak hubungan Anda dengan bawahan maupun atasan serta dapat menyebabkan stres. Jadi, selama anda dikendalikan oleh emosi negatif Anda justru anda tidak bisa mencapai potensi terbaik dari diri anda. Solusinya, lepaskan emosi negatif melalui teknik pendayagunaan pikiran bawah sadar sehingga anda maupun orang-orang di sekitar Anda tidak menerima dampak negatif dari emosi negatif yang muncul.

Mengelola emosi diri sendiri, Anda jangan pernah menganggap emosi negatif atau positif itu baik atau buruk. Emosi adalah sekedar sinyal bagi kita untuk melakukan tindakan untuk mengatasi penyebab munculnya perasaan itu. Jadi emosi adalah awal bukan hasil akhir dari kejadian atau peristiwa. Kemampuan kita untuk mengendalikan dan mengelola emosi dapat membantu Anda mencapai kesuksesan. Ada beberapa langkah dalam mengelola emosi diri sendiri, yaitu: Pertama adalah menghargai emosi dan menyadari dukungannya kepada Anda. Kedua berusaha mengetahui pesan yang disampaikan emosi, dan meyakini bahwa kita pernah berhasil menangani emosi ini sebelumnya. Ketiga adalah dengan bergembira kita mengambil tindakan untuk menanganinya. Kemampuan kita mengelola emosi adalah bentuk pengendalian diri yang paling penting dalam manajemen diri, karena kitalah sesungguhnya yang mengendalikan emosi atau perasaan kita, bukan sebaliknya (walgito:1987).

Memotivasi diri sendiri adalah menata emosi sebagai alat untuk mencapai tujuan merupakan hal yang sangat penting dalam kaitan untuk memberi perhatian, untuk memotivasi diri sendiri dan menguasai diri sendiri, dan untuk berkreasi. Kendali diri emosional-menahan diri terhadap kepuasan dan mengendalikan dorongan hati-adalah landasan keberhasilan dalam berbagai bidang. Ketrampilan memotivasi diri memungkinkan terwujudnya kinerja yang tinggi dalam segala bidang. Orang-orang yang memiliki ketrampilan ini cenderung jauh lebih produktif dan efektif dalam hal apapun yang 
mereka kerjakan. Mengenali emosi orang lain. Mengenali emosi orang lain berarti kita memiliki empati terhadap apa yang dirasakan orang lain. Penguasaan ketrampilan ini membuat kita lebih efektif dalam berkomunikasi dengan orang lain. Inilah yang disebut sebagai komunikasi empatik. Berusaha mengerti terlebih dahulu sebelum dimengerti. Ketrampilan ini merupakan dasar dalam berhubungan dengan manusia secara efektif.

Mengelola emosi orang lain Jika ketrampilan mengenali emosi orang lain merupakan dasar dalam berhubungan antar pribadi, maka ketrampilan mengelola emosi orang lain merupakan pilar dalam membina hubungan dengan orang lain. Manusia adalah makhluk emosional. Semua hubungan sebagian besar dibangun atas dasar emosi yang muncul dari interaksi antar manusia. Keterampilan mengelola emosi orang lain merupakan kemampuan yang dahsyat jika kita dapat mengoptimalkannya. Sehingga kita mampu membangun hubungan antar pribadi yang kokoh dan berkelanjutan. Dalam dunia industri hubungan antar korporasi atau organisasi sebenarnya dibangun atas hubungan antar individu. Semakin tinggi kemampuan individu dalam organisasi untuk mengelola emosi orang lain.

Memotivasi orang lain Ketrampilan memotivasi orang lain adalah kelanjutan dari ketrampilan mengenali dan mengelola emosi orang lain. Ketrampilan ini adalah bentuk lain dari kemampuan kepemimpinan, yaitu kemampuan menginspirasi, mempengaruhi dan memotivasi orang lain untuk mencapai tujuan bersama. Hal ini erat kaitannya dengan kemampuan membangun kerja sama tim yang tangguh dan andal. Jadi, sesungguhnya delapan ketrampilan ini merupakan langkah-langkah yang berurutan. Anda tidak dapat memotivasi diri sendiri kalau Anda tidak dapat mengenali dan mengelola emosi diri sendiri. Setelah Anda memiliki kemampuan dalam memotivasi diri, barulah kita dapat memotivasi orang lain (nafis:2011). Maka Menyadari akan arti pentingnya mahasiswa untuk mengembangkan kecerdasan dan kreativitasnya, maka sebagai sesama mahasiswa kita dianjurkan untuk meluangkan waktu secara teratur bagi rekan yang lain untuk mengembangkan kemampuan bahasa misalnya, biasakan menjalin percakapan atau komunikasi kepada siapa pun dia tanpa memandang suku,jenis kelamin ,dll.Sementara untuk memuaskan kebutuhan ilmiahnya, mereka bisa diajak menjelajahi dunianya dengan cara melakukan eksperimen. Kaitkan semua kegiatan diatas sebagai suatu aktivitas yang menyenangkan dan selalu ditunggu oleh siswa. Ini adalah hal-hal yang merangsang pengembangan kecerdasan mahasiswa (Tifanni, 2011).

\section{Pemahaman Hablumminnannas}

Menurut Thimas (1996:21) Agama dapat mempengaruhi sikap praktis manusia terhadap berbagai aktivitas kehidupan sehari-hari. Agama dipandang sebagai jalan hidup yang dipegang dan diwarisi turun temurun oleh masyarakat manusia. Agar hidup menjadi damai, tertib dan tidak kacau. yang menjadi unsur agama adalah:

a) Pengakuan bahwa ada kekuatan gaib yang menguasai atau mempengaruhi kehidupan manusia. 
b) Keyakinan bahwa kehidupan manusia tergantung pada adanya hubungan baik antar manusia dengan kekuatan gaib.

c) Sikap emosional pada hati manusia terdapat kekuatan gaib, seperti sifat takut, hormat, cinta, penuh harap,pasrah, dan lain-lain.

d) Tingkah laku tertentu yang diamati, seperti sholat,sedekah,puasa,zakat, suka menolong,tidak korupsi, dan lain sebagainya.

Menurut Dahlan (1994:279)

Pemahaman berasal dari kata faham atau yang memiliki arti tanggap, mengerti benar, pandangan, ajaran. Disini ada pengertian pemahaman menurut Muhammad Ali (1996:42) yaitu kemampuan memahami arti suatu bahan pelajaran, seperti menafsirkan,menjelaskan atau meringkas atau merangkum suatu pengertian kemampuan macam ini lebih tinggi dari pada pengetahuan. Menurut Dimyati dan mudjono (2009:201) sebagai kegiatan yang berupaya untuk mengetahui tingkat pemahaman dalam mencapai tujuan yang ditetapkan maka evaluasi hasil belajar memiliki sasaran berupa ranah-ranah yang terkandung dalam tujuan yang diklasifikasikan menjadi tiga ranah kognitif, ranah afektif dan ranah psikomotorik. Pemahaman dapat dibedakan menjadi tiga kategori, yaitu: Tingkat terendah yakni pemahaman terjemahan mulai dari terjemahan dalam arti sebenarnya. Tingkat sedang yakni pemahaman penafsiran.

Tingkat tertinggi yakni pemahaman ekstrapolasi.

Agama Islam terdiri dari tiga unsur, aqidah (rukun iman), ibadah (rukun Islam), dan insan (akhlak). Ihsan adalah puncak ibadah dan akhlak yang senantiasa menjadi target seluruh hamba Allah SWT. Sebab insan menjadikan kita sosok yang mendapatkan kemuliaan dariNya. Sebaliknya seorang hamba yang tidak mampu mencapai target ini, menyebabkan kehilangan kesempatan yang sangat mahal untuk menduduki posisi terhormat dimata Allah SWT. Ihsan itu adalah bahwa kamu menyembah Allah tetapi kamu tidak melihat-Nya, jika kamu tidak melihat-Nya bahwa sesungguhnya Dia melihat kamu. Ihsan juga adalah melakukan ibadah dengan khusyuk, ikhlas dan yakin bahwa Allah senantiasa mengawasi apa yang dilakukannya. Islam dibangun diatas tiga landasan utama yaitu Iman, Islam dan Ihsan oleh karenanya seorang muslim hendaklah tidak memandang insan itu hanya sebatas akhlak yang utama saja melainkan harus dipandang sebagai bagian dari aqidah dan bagian terbesar dari keislamannya.

Dalam mengejewantahkan ihsan bagi manusia sebagai makhluk sosial seperti manusia, khususnya kaum muslim ialah berbuat baik. Karena dengan pemahaman ihsan ini kita selalu merasa diawasi oleh Allah yang Maha Melihat dengan begitu kita tidak akan melakukan perbuatan buruk kalaupun sampai terbesit maka tetap saja kita tidak akan mau mengerjakannya disebabkan insan tadi. Selain berbuat baik, insan juga merupakan salah satu cara agar kita bisa khusyuk dalam beribadah kepada Allah SWT. Tiga aspek pokok dalam Ihsan meliputi tiga aspek yang fundamental. Ketiga hal tersebut adalah ibadah, muamalah dan akhlak. Ketiga hal inilah yang menjadi pokok batasan dalam insan. Ibadah Kita berkewajiban insan dalam beribadah yaitu dengan 
Al-Fikra: Jurnal IImiah Keislaman, Vol. 16, No. 2,Juli - Desember, 2017 (269 304 )

menunaikan semua jenis ibadah, seperti shalat, puasa dan haji dengan cara yang benar yaitu dapat ditunaikan oleh seorang hamba kecuali jika saat pelaksanaan ibadah-ibadah tersebut ia penuhi dengan cita rasa yang sangat kuat, juga dengan kesa Antara iman, Islam dan insan, ketiganya tak bias dipisahkan oleh manusia di dunia ini, kalau diibaratkan hubungan diantara ketiganya adalah segitiga sama sisi yang sisi satu dan sisi lainnya berkaitan erat. Segitiga tersebut tidak akanterbentuk kalau ketiga sisinya tidak saling mengait.jadi manusia yang bertaqwa harus bias meraih dan menyeimbangkan antara iman, Islam dan ihsan.

Jadi, pemahaman agama adalah kemampuan pemahaman seseorang dalam memahami, menghayati dan menerjemahkan ajaran agama (Islam) dalam iman, Islam dan ihsan di kehidupan sehari - hari. Untuk kebaikan hidup manusia, Alquran (QS Ali Imran, 3:112) menekankan dua hal pokok saja, yaitu hubungan dengan Allah (Hablumminnallah) dan hubungan dengan sesama manusia (Hablumminnanas). Tanpa terjalinnya dua hubungan tersebut dengan baik, hidup dan kehidupan manusia terancam sengsara dan hina. Bahkan bentuk -bentuk ritual khusus yang diformatkan untuk pengokohan hubungan manusia dengan Allah, seperti shalat, shaum, dzikir, dan lain sebagainya.tetap diorientasikan untuk pemantapan hubungan manusia dengan sesamanya. Dalam hadis qudsi yang diriwayatkan Imam Baihaqi, Nabi Muhammad saw bersabda:

"Allah hanya akan menerima shalat dari orang yang merendahkan diri di hadapan keagungan-Ku, tidak sombong terhadap sesama
makhluk-Ku, menghabiskan siangnya dengan zikir kepada-Ku, tidak secara sengaja melakukan dosa dimalam harinya, suka memberi makan bagi orang yang lapar, memberi perlindungan bagi orang yang kesulitan, menyayangi yang kecil, dan menghormati yang besar."

Begitu juga dengan hakikat iman, Bahwa keimanan seseorang baru diakui kebenarannya apabila manifest pada tindakan sosial.

"Orang beriman itu bukan orang kenyang sendiri, padahal tetangga sedang lapar."(HR Baihaqi) "Seseorang tidak dikatakan beriman, sebelum dia menginginkan (kebaikan) bagi orang lain seperti bagi dirinya sendiri."(HR Bukhari).

Dengan dukungan ayat dab hadishadis di atas, konsep hablumminnallah dan hablumminnannas bukan dua hal yang mendua, melainkan dua hal yang menyatu. Artinya, interaksi sosial seseorang tidak netral dari nilai-nilai Ilahiyah, ketika dia merealisasikan hubungan sosialnya kepada sesamanya, pada hakikatnya dia sedang mengaktualisasikan hubungan dengan Rabb-Nya. Tiga konsep dari alquran yang dapat dikembangkan sebagai teori hablumminnannas, konsep-konsep tersebut adalah tadafu', ta'aruf dan ta'awun. Tadafu'M.Quraish Shihab (2007, 1:537-538) menjelaskan, bahwa hidup adalah pertarungan antara kebenaran dan kebatilan. Apabila tidak ada yang tampil menghadapi kebatilan dan menghentikan kezaliman, bumi sebagai tempat tinggal manusia akan diliputi oleh kekejaman dan penganiayaan. Apabila kezaliman tidak dihadapi, dia akan meningkat dan terus 
Windayani, Khairil Anwar; Pengaruh Prilaku Belajar, Kecerdasan Emosional dan Pembahasan Hablumminnannas Terhadap Kepribadian Akademik Di Institut Agama Islam Tafaqquh Fiddin Dumai

meningkat kualitas dan kuantitasnya sehingga akan membinasakan umat manusia. Disinilah orang beriman mendapat amanah untuk menghadapi para perusak agar bumi selamat dari kebinasaan.

Dr. Abdul Karim Khatib dalam kitabnya (1:311) menafsirkan ayat tersebut sebagai saling tolak antara manusia, yaitu antara kebaikan dan keburukan, antara hak dan kebatilan, antara orang kaya dan orang miskin, antara orang kuat dan orang lemah, antara individu dan individu, antara kelompok dan kelompok, dan antara bangsa dan bangsa. Sifat saling tolak menolak ini terjadi pada semua tingkat dan segmen kehidupan. Dialah Allah Ta'ala yang menggerakkan roda aktivitas dan membangkitkan berbagai dimensi kehidupan di bumi. Sebagaimana tercantum pada QS Al-Baqarah,2:49, sebelum perang terjadi tetara Thalut diuji terlebih dahulu oleh Allah, yaitu dengan sungai. Diumumkan agar tidak meminum air dari sungai tersebut kecuali sekedar cedukan tangan."Orang yang minum dari padanya bukan pengikutku, kata Thalut,"kecuali kalau hanya sekedar cedukan tangan." Ternyata kebanyakan tentaranya bukan tentara yang baik, mereka minum sesukanya.hanya sedikit sajatentara yang tidak minumdan taat kepadanya. Ujian tersebut berdampak langsung terhadap mentalitas dan keberanian mereka untuk berperang. Tentara yang minum itu bermental pengecut. Ketika menyeberangi sungai, mereka menyatakan tidak sanggup perang menghadapi tentara Jalut. Hal ini berbeda dengan tentara yang taat. Sekalipun jumlahnya lebih sedikit, mereka memiliki keyakinan yang kokoh atas janji dan pertolongan Allah Ta'ala. Mereka maju dengan gigih sehingga dapat mengalahkan Jalut dan tentaranya. Padahal, jumlah mereka lebih banyak dan peralatannya lebih lengkap. Hal ini mengandung pelajaran penting bagi masyarakat muslim dalam menghadapi konflik atau peperangannya. Sistem keyakinan (keimanan) kepada yang Mahamutlak sesungguhnya merupakan kekuatan dan nilai tertinggi yang harus diagungkannya di atas segala dan kepentingan dalam menata dan mengembangkan seluruh kehidupannya.

Uraian ini bukan untuk menjelaskan teori konflik dari perspektif Islam, sebab teori konflik memiliki perbedaan mendasar dengan Islam dalam memandang agama. Teori konflik menyatakan bahwa agama bertanggungjawab atas pemerasan, mendukung penindasan, dan menimbulkan kejahatan dalam masyarakat. Pada derajat atau tataran tertentu, bisa saja kaidah tadafu' dalam Al-Quran didekatkan dengan teori konflik, khususnya pada tataran aktual. Akan tetapi, pada tataran konsep atau asumsi dasarnya terdapat perbedaan yang prinsipal. Adapun kaidah tadafu' berlandaskan pada asumsi dasar bahwa : Manusia sebagai makhluk Tuhan yang harus mengabdikan totalitas hidupnya kepada-Nya, sehingga seluruh pertimbangan, keputusan dan tindakannya harus diselaraskan dengan ajaran-Nya. Dan Tadafu'atau konflik merupakan proses alamiah (sunnatullah) yang harus dilalui sebagai konsekuensi dari hakikat fitrah manusia yang memiliki kecendrungan dan tanggungjawab untuk membela kebenaran dan keadilan.

Kaidah atau konsep ta'aruf diangkat dari Firman Allah Ta'ala 
Al-Fikra: Jurnal IImiah Keislaman, Vol. 16, No. 2,Juli - Desember, 2017 (269 304 )

yang terungkap dalam QS AlHujurat, 49:13),

"Hai manusia, sesungguhnya Kami menciptakan kamu dari orang laki-laki dan seorang perempuan dan menjadikan kamu berbangsa-bangsa dan bersuku, supaya kamu saling mengenal. Seseungguhnya orang yang paling mulia di antara kamu di sisi Allah adalah orang yang paling bertakwa diantara kamu. Sesungguhnya Allah Maha Mengetahui lagi Maha Mengenal."

Konsep ta'aruf dengan demikian menghendaki pengembangan interaksi berdasarkan atas pengetahuan dan pemahaman yang benar untuk menciptakan kebersamaan (bermasyarakat) yang solid dan harmonis. Kebersamaan tersebut tidak berarti meniadakan keunggulan, kelebihan dan persaingan di dalamnya, terlebih bahwa kebersamaan tersebut berlatar belakang dari berbagai perbedaan. Keunggulan, kelebihan dan pesaingan yang ada akan tetap diberi tempat untuk berkembang dengan syarat bernaung di bawah nilai ketakwaan. Semuanya harus berkembang dan diukur dengan ketakwaan. Dengan berdasar pada ketakwaan, persaingan , keunggulan, kelebihan bahkan kelemahan akan menjadi wahana untuk pengembangan kebaikan sehingga mampu mengantisipasi efek-efek negatif yang timbul.

Maka, hadirnya konsep ta;aruf kemudian disusul dengan kalimat, "Sesungguhnya orang yang paling mulia diantara kalian adalah orang yang paling takwa". Sesuai dengan karakter penyajian kalimatnya, ketakwaan tersebut diharapkan menjadi prinsip yang menyeluruh dalam pengembangan ta'aruf. Jika dihubungkan dengan kaidah tadafu' di atas, ternyata kaidah ta'aruf menjadi solusi bagi konflik (tadafu') tersebut. Begitu juga dengan kaidah ta'awun yang akan memberikan gambaran lebih jelas dan operasional dalam pengembangan dan penataan kehidupan bermasyarakat. Dengan demikian, kehadiran tiga kaidah tersebut tidak akan saling berbenturan, melainkan justru saling melengkapi dan mengokohkan satu sama lain. Sedianya memang demikian, karena ketiga dikembangkan dari satu sumber sama dan dari prinsip tauhid. Konsep ini diangkat dari QS AlMa'idah : 2, yang berbunyi :

"Saling tolong-menolonglah dalam kebajikan dan ketakwaan dan janganlah saling tolong-menolong dalam dosa dan permusuhan."

Konsep ini mengakui adanya perbedaan sekaligus mengakui bahwa setiap (individu) memiliki potensi dan kekuatan, sekecil apapun adanya. Konsep ini menghendaki agar perbedaan potensi dan kekuatan (keunggulan, kelemahan, kaya, miskin dan lain sebagainya) fungsional secara positif dalam membangun kehidupan bersama yang harmonis.

Konsep ta'awun memiliki makna yang komprehensif dan sistemik. Itu mengapa, sebagian ulama tafsir menafsirkannya sebagai prinsip besar dalam kehidupan secara menyeluruh. Hadis dari Nabi Muhammad saw, menganalogikan ta'awun sebagai suatu bangunan yang saling menguatkan atau suatu badan. Apabila ada sebagian yang sakit, rasa sakit tersebut akan terasa oleh bagian lainnya. Tubuh manusia secara mikro merupakan representasi dari alam secara 
Windayani, Khairil Anwar; Pengaruh Prilaku Belajar, Kecerdasan Emosional dan Pembahasan Hablumminnannas Terhadap Kepribadian Akademik Di Institut Agama Islam Tafaqquh Fiddin Dumai

makro. Munculnya gerak sederhanadari manusia merupakan hasil perpaduan dan kerjasama yang kompleks dari berbagai unsur dan elemen yang ada dan terlibat di dalamnya. Semua bekerja secara sistemik sehingga menghasilkan gerak harmonis melalui proses alamiah yang sangat rapidan terencana.

Adanya penekanan prinsip takwa dan kebajikan pada ta'awun sangat beralasan. Alquran tidak membiarkan satu celah pun yang mungkin bisa jadi jalan kemungkaran atau kedzaliman, melainkan segera dibentengi supaya tidak memberi kesempatan untuk lolosnya suatu kemungkaran. Struktur sebagai perangkat di mana sebagian dapat mempergunakan atau memberdayakan sebagian yang lainnya bisa jadi rentan dengan upaya-upaya yang mengandung aniaya atau kedzaliman. Oleh karena itu, ta'awun tidak dibiarkan kosong dari nilai yang membentenginya agar memastikan bahwa fungsionalnya seseorang bagi yang lain adalah fungsional secara positif. Adapun fungsional yang mengandung fasad (kerusakan) atau kedzaliam sama sekali tidak ada tempatnya.

\section{Kepribadian Akademik}

Kepribadian merupakan pola khas seseorang dalam berpikir, merasakan dan berperilaku yang relatif stabil dan dapat diperkirakan (Dorland, 2002). Kepribadian juga merupakan jumlah total kecenderungan bawaan atau herediter dengan berbagai pengaruh dari lingkungan serta pendidikan, yang membentuk kondisi kejiwaan seseorang dan mempengaruhi sikapnya terhadap kehidupan (Weller, 2005). Berdasarkan pengertian tersebut, dapat disimpulkan bahwa kepribadian meliputi segala corak perilaku dan sifat yang khas dan dapat diperkirakan pada diri seseorang, yang digunakan untuk bereaksi dan menyesuaikan diri terhadap rangsangan, sehingga corak tingkah lakunya itu merupakan satu kesatuan fungsional yang khas bagi individu itu.

Secara akademik, kepribadian dapat diartikan sebagai sifat yang khas dan terukur pada diri seseorang dalam kaitannya dengan kemampuan memahami pendidikan dan bereaksi di bidang akademik. Kajian Islam tentang Kepribadian. Terdapat banyak perbedaan yang bersifat individu yang terjadi pada masing-masing orang, baik dari segi warna kulit, logat bicara, kemampuan fisik, kecerdasan, kemampuan belajar maupun cirri cirri kepbribadian. Menurut Alport mengatakan bahwa tidak ada manusia karena manusia itu unik (unik person). Manusia melaksanakan perbuatannya untuk memenuhi naluri dan kebutuhan kebutuhan jasmaninya. Kumpulan perbuatan tersebut merupakan tingkah laku manusia, dan tingkah laku bergantung pada pemahaman pemahaman (mafahim) manusia tentang segala sesuatu ( assya), aktifitas dan kehidupan. Tingkah lakukan yang menunjukkan kepribadian, sedangkan tampan, postur tubuh, warna kulit, jenis kelamin tidak menentukan kepribadian. Menurut al-Zarkali bahwa Tentang kepribadian manusia dapat melalui tiga sudut yaitu : Jasad ( fisik ) tentang organism dan sifat - sifatnya. Jiwa ( psikis ) tentang hakikat dan sifat uniknya; Jasad dan jiwa ( psikofisik) berupa akhlak, perbuatan, gerakan dan sebagainya. Kepribadian adalah 
Al-Fikra: Jurnal IImiah Keislaman, Vol. 16, No. 2,Juli - Desember, 2017 (269 304 )

metode berfikir manusia terhadap realita, kepribadian juga kecendrungan manusia terhadap realita, dan dengan arti lain, kepribadian manusia adalah pola pikir (aqliyah) dan pola jiwa (annafsiya) Firman Allah SWT dalam QS. Al-Hasyr 59:7 :

"Apa saja harta rampasan (fai-i yang diberikan Allah kepada Rasul-Nya (dari harta benda ) yang berasal dari penduk kota-kota Maka adalah Allah, untuk rasul, kaum kerabat, anak-anak yatim, orang -orang miskin dan orang - orang yang di dalam perjalanan, supaya harta itu jangan beredar di antara orang - orang Kaya saja di antara kamu. Apa yang diberikan Rasul kepadamu, maka terimalah. Dan apa yang dilarangnya bagimu, Maka tinggalkanlah. Dan bertaqwalah kepada Allah. Sesungguhnya Allah amat keras hukumannya."

\section{Faktor Yang Mempengaruhi Kepribadian Akademik}

Meskipun kepribadian seseorang itu relatif konstan, namun dalamkenyataannya sering ditemukan adanya perubahan kepribadian. Perubahan itu dapat disebabkan oleh berbagai faktor. Menurut Schoupenhouer, kepribadian itu lebih banyak dipengaruhi oleh faktor bawaan daripada faktor dari luar. Hal ini didukung olehJ.J. Roseseau yang berpendapat bahwa segala yang suci dari tangan Tuhan, rusak di tangan manusia. Anak manusia itu sejak lahir ada di dalam keadaan yang suci, tetapi karena dididik oleh manusia sehingga menjadi rusak
(Agus Sujianto, Halem Lubis \& Taufik Hadi, 2008: 4). Contohnya adalah orang yang hidup dengan bakatnya, yang telah dibawa sejak lahir, yang memang sukar sekali dihilangkan dengan pengaruh apapun juga.

Hal tersebut kemudian dipertentangkan oleh John Locke dengan teori Tabula rasanya, yang berpendapat bahwa anak sejak lahir masih seperti tabula rasa, dan baru akan dapat berisi bila ia menerima sesuatu dari luar, lewat alat inderanya. Karena itu pengaruh dari luarlah yang lebih kuat daripada pembawaan manusia. Melihat pertentangan tersebut, W. Stern mengajukanteorinya yang dikenal dengan teori perpaduan yang berpendapat bahwa kedua kekuatan itu sebenarnya berpadu menjadi satu. Keduanya saling memberikan pengaruh.

Sedangkan menurut Syamsu Yusuf \& Juntika Nurihsan (2007: 11) faktorfaktor yang dapat menyebabkan terjadinya perubahan kepribadian di antaranya sebagai berikut:

1). Faktor fisik, seperti: gangguan otak, kurang gizi (malnutrisi), mengonsumsi obat-obat terlarang (NARKOBA), minuman keras, dan gangguan organik (sakit atau kecelakaan).

2). Faktor lingkungan sosial budaya, seperti: krisis politik, ekonomi, dan keamanan yang menyebabkan terjadinya masalah pribadi (stress, depresi) dan masalah sosial (pengangguran, premanisme, dan kriminalitas).

3). Faktor diri sendiri, seperti: tekanan emosional (frustasi yang berkepanjangan), dan identifikasi atau imitasi terhadap orang lain yang berkepribadian menyimpang.

Selanjutnya Syamsu Yusuf \& Juntika Nurihsan (2007:20-33) juga membagi faktor yang mempengaruhi 
Windayani, Khairil Anwar; Pengaruh Prilaku Belajar, Kecerdasan Emosional dan Pembahasan Hablumminnannas Terhadap Kepribadian Akademik Di Institut Agama Islam Tafaqquh Fiddin Dumai

kepribadian kedalam dua hal, yaitu faktor hereditas (genetika) dan faktor lingkungan (environment). Faktor hereditas dalam kaitannya dengan perkembangan kepribadian adalah 1) sebagai sumber bahan mentah kepribadian seperti fisik, inteligensi, dan temperamen; 2) membatasi perkembangan kepribadian (meskipun kondisi lingkungannya sangat baik/kondusif, perkembangan kepribadian itu tidak bias melebihi kapasitas atau potensi genetika); dan 3) mempengaruhi keunikan kepribadian. Faktor lingkungan yang turut mempengaruhi kepribadian yaitu keluarga, kebudayaan, dan kampus. Keluarga dipaandang sebagai penentu utama pembentukan kepribadian karena keluarga merupakan kelompok sosial pertama yang menjadi pusat identifikasi mahasiswa. Selain itu, mahasiswa banyak menghabiskan waktunya di lingkungan keluarga. Para anggota keluarga juga orangorang yang sangat berpengaruh bagi pembentukan kepribadian mahasiswa. Dan terakhir, keluarga juga dipandang sebagai lembaga yang dapat dapat memenuhi kebutuhan manusiawi terutama bagi pengembangan kepribadiannya. Faktor kebudayaan mempengaruhi individu untuk mengikuti pola-pola perilaku tertentu yang telah dibuat orang lain untuk kita. Setiap kelompok masyarakat (bangsa, ras, atau suku) memilik tradisi, adat, atau kebudayaan yang khas. Kebudayaan suatu masyarakat memberikan pengaruh terhadap setiap warganya, baik yang menyangkut cara berpikir, cara bersikap, atau cara berperilaku. Faktor lingkungan kampus yang dinilai dapat mempengaruhi kepribadian yaitu iklim emosional kelas, sikap dan perilaku dosen, disiplin (tata-tertib), prestasi belajar, dan penerimaan teman sebaya. Hurlock dalam Muh. Farozin \& Kartika Nur Fathiyah (2003:18-21) mengemukakan faktor-faktor yang dapat mempengaruhi kepribadian seseorang adalah pengalaman awal, pengaruh budaya, ciri-ciri fisik, kondisi fisik, keberhasilan\&kegagalan,

penerimaan sosial, pengaruh keluarga, dan tingkat penyesuaian.

Faktor pengalaman awal biasanya dialami pada masa kanakkanak dan ingatan akan hal itu akan sangat berpengaruh karena pengalaman meninggalkan kesan yang tidak terhapuskan pada konsep diri anak. Sedangkan dalam faktor pengaruh budaya, kelompok budaya menetapkan model untuk pola kepribadian yang disetujui dan menekan individu-individu yang tergabung di dalamnya untuk berperilaku sesuai dengan norma budaya yang bersangkutan sehingga pada akhirnya individu tersebut menyesuaikan diri mengikuti pola perilaku yang telah ditetapkan kelompok budaya dan perilaku tersebut menetap menjadi kecenderungan pola perilaku individu. Kemudian dalam faktor ciriciri fisik, secara langsung bentuk tubuh menentukan apa yang dapat dan yang tidak dapat dilakukan seseorang. Sedangkan secara tidak langsung ciri-ciri fisik menentukan bagaimana seseorang merasa tentang tubuhnya. Semakin banyak aktivitas dilakukan seseorang sesuai dengan ciri fisiknya akan semakin meningkatkan konsep diri positifnya dan pada akhirnya akan semakin mengembangkan kepribadian positif individu yang bersangkutan.

Faktor yang selanjutnya yaitu kondisi fisik, dua aspek kondisi fisik yang mempengaruhi kepribadian yaitu kesehatanumum dan cacat jasmani. Kesehatan yang baik 
Al-Fikra: Jurnal IImiah Keislaman, Vol. 16, No. 2,Juli - Desember, 2017 (269 304)

memungkinkan seseorang ikut serta dalam kegiatan kelompoknya sehingga lebih diterima kelompok dan pada akhirnya menentukan konsep diri positif yaitu sebagai individu yang diterima dengan baik oleh lingkungannya. Sedangkan cacat jasmani menentukan kepribadian seseorang melalui cara pandang seseorang terhadap kecacatannya dan aktivitas yang dapat dilakukan dengan kecacatan tersebut. Semakin banyak aktivitas dapat dilakukan oleh individu yang cacat akan semakin meningkatkan konsep diri positif yang pada akhirnya berpengaruh pada terbentuknya perkembangan kepribadian yang sehat. Faktor yang tidak kalah pentingnya yaitu keberhasilan dan kegagalan. Kepribadian juga ditentukan oleh anggapan seseorang mengenai dirinya yaitu sebagai seseorang yang sukses atau sebagai orang yang selalu gagal. Sedangkan faktor penerimaan sosial akan mempengaruhi setiap keinginan individu untuk mengembangkan sifat-sifat yang disetujui secara sosial dan selanjutnya mempengaruhi konsep diri dan kepribadiannya.

Faktor keluarga juga ikut berperan dalam pembentukan kepribadian. Keluarga yang mengembangkan pola asuh yang menerima dan menghargai individu akan meningkatkan konsep diri positif dan selanjutnya berpengaruh positif terhadap kepribadian, begitu pula sebaliknya. Faktor yang terakhir yaitu tingkat penyesuaian. Tingkat penyesuaian diri yang tinggai memudahkan penerimaan lingkungan sosial terhadap individu yang bersangkutan dan selanjutnya berpengaruh positif terhadap kepribadian. Jadi dapat disimpulkan bahwa kepribadian seseorang dapat dipengaruhi oleh faktor intern dan faktor ekstern. Faktor intern meliputi faktor fisik (ciriciri fisik dan kondisi fisik) dan faktor diri sendiri (genetika, sifat). Sedangkan faktor ekstern meliputi faktor lingkungan sosial dan budaya. Menurut Soffandi (2000:326) menerangkan adanya perbedaan manusia dari segi kulit, karakter, temperamen dan emosi yang kesemuanya merupakan perbedaan yang bersifat natural dan perbedaan itu sudah pasti ada.

\section{Kerangka Berpikir}

Kerangka pemikiran merupakan kerangka hubungan antara variable-variabel yang diamati dan diukur melalui penelitian yang dilakukan. Kerangka pemikiran adalah gambaran terhadap penelitian yang dilakukan serta memberikan landasan yang kuat disesuaikan pada masalah dan bahasan yang dipilih. Berdasarkan landasan teori dan pemikiran terdahulu, maka dapat digambarkan suatu bagan kerangka pemikiran mengenai analisis pengaruh perilaku belajar, kecerdasan emosional dan pemahaman hablun minnannas terhadap kepribadian akademik mahasiswa di Institut Agama Islam Tafaqquh Fiddin Dumai sebagai berikut: 
Windayani, Khairil Anwar; Pengaruh Prilaku Belajar, Kecerdasan Emosional dan Pembahasan Hablumminnannas Terhadap Kepribadian Akademik Di Institut Agama Islam Tafaqquh Fiddin Dumai

Gambar 2.1

Kerangka Pikir

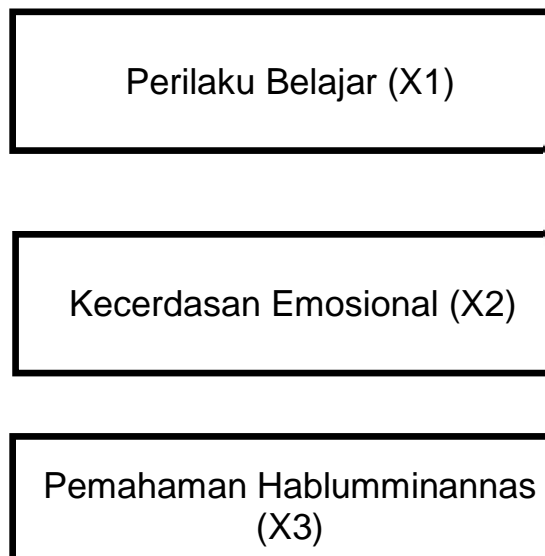

Dari diagram tersebut dapat dijelaskan sebagai berikut: Variabel perilaku belajar berpengaruh terhadap kepribadian akademik. Variabel kecerdasan emosional berpengaruh terhadap kepribadian akademik. Variabel pemahaman hablumminnannas berperngaruh terhadap kepribadian akademik. Variabel prilaku belajar, kecerdasan emosional dan hablumminnannas berpengaruh secara serentak terhadap kepribadian akademik.

\section{Metode penelitian}

Rancangan penelitian ini adalah
penelitian lapangan
menggunakan kaedah menggunakan kaedah kuantitatif
adapun pendekatannya yaitu kolerasional. Adapun alasan penggunaan ini adalah karena ingin menguji variabel perilaku belajar, kecerdasan emosional dan pemahaman hablumminnannas
Kepribadian Akademik

(Y)

terhadap kepribadian akademik di Institut Agama Islam Tafaqquh Fiddin Dumai. Rancangan penelitian ini merupakan pedoman yang berisi langkah-langkah yang harus diikuti oleh peneliti untuk melakukan penelitiannya. Rancangan penelitian ini harus dibuat secara sistematis dan logis sehingga dapat dijadikan pedoman yang betul - betul diikuti (Sugiyono, 2011). Penelitian ini mengambil tempat di Institut Agama Islam Tafaqquh Fiddin Dumai. Yang beralamat Jalan Utama Karya No. 3 Bukit Batrem II Kecamatan Dumai Timur Kota Dumai. Adapun subjek Penelitian :Mahasiswa ngkatan 2014,2015,2016,2017 Institut Agama Islam Tafaqquh Fiddin Dumai. Artinya Populasi penelitian ini adalah seluruh Mahasiswa Angkatan 2014,2015,2016,2017 Institut Agama Islam Tafaqquh Fiddin Dumai yang berstatus mahasiswa aktif. Berdasarkan data yang diperoleh dari pihak Sekolah Tinggi, Jumlah Populasi Mahasiswa angkatan 2014,2015,2016,2017 berjumlah 303 orang. 
Tabel 2.3

Jumlah Data Mahasiswa

\begin{tabular}{|c|c|r|r|}
\hline \multicolumn{1}{|c|}{ NO } & \multirow{2}{*}{ TAHUN } & \multicolumn{2}{|c|}{ JUMLAH MAHASISWA } \\
\cline { 3 - 4 } & & $\mathbf{L}$ & $\mathbf{P}$ \\
\hline 1. & 2014 & 21 & 35 \\
\hline 2. & 2015 & 32 & 65 \\
\hline 3. & 2016 & 26 & 35 \\
\hline 4. & 2017 & 35 & 54 \\
\hline & Total & 114 & 189 \\
\hline & & Total & 303 \\
\hline
\end{tabular}

Sumber: Data Pusat pelayanan terpadu IAI TF Dumai 2017

\section{Teknik Analisis Data}

Analisis regresi berganda digunakan oleh peneliti, bila peneliti bermaksud meramalkan bagaimana keadaan (naik turunnya) variabel dependen (kriterium), bila dua atau lebih variabel independen sebagai faktor prediktor dimanipulasi (dinaik turunkan nilainya). Jadi analisis regresi ganda dilakukan bila jumlah variabel independennya minimal dua (Sugiyono, 2011). Analisis regresi berganda digunakan untuk mengetahui apakah terdapat pengaruh yang signifikan dari variabel terikat (dependen) atau lebih dari satu variabel bebas (independen). Adapun variabel terikat dalam penelitian ini adalah Kepribadian Akademik di Institut Agana Islam Tafaqquh Fiddin Dumai. Sedangkan variabel bebas dalam penelitian ini adalah adalah perilaku belajar, keserdasan emosional, pemahaman hablun minnannas. Model hubungan Perilaku belajar, Kecerdasan Emosional, Pemahaman Hablun Minnannas terhadap Kepribadian akademik di Institut Agama Islam Tafaqquh Fiddin dumai dapat disusun dalam persamaan linier sebagai berikut:

$\mathrm{Y}=\mathrm{a}+\mathrm{b} 1 \mathrm{X} 1+\mathrm{b} 2 \mathrm{X} 2+\mathrm{b} 3 \mathrm{X} 3+\mathrm{ei}$

Dimana:

Y :Kepribadian

Akademik

$$
\begin{aligned}
& \text { a : konstanta } \\
& \text { b1-b2 : koefisien } \\
& \text { regresi merupakan besarnya } \\
& \text { perubahan variabel terikat akibat } \\
& \text { perubahan tiap-tiap unit variabel }
\end{aligned}
$$

Uji prasyarat (uji asumsi klasik) digunakan untuk menguji apakah regresi benar-benar menunjukan hubungan yang signifikan dan refresentatif. Asumsi-asumsi dasar tersebut dikenal sebagai asumsi klasik (Hasan, 1999: 268). Ada tiga uji asumsi kelasik, yaitu:

1. Uji normalitas data

Uji normalitas digunakan untuk menguji apakah model regresi mempunyai distribusi normal ataukah tidak. Asumsi normalitas merupakan persyaratan yang sangat penting pada pengujian kebermaknaan (signifikansi) koefisien regresi. Model regresi yang baik adalah model regresi yang memiliki distribusi normal atau mendekati normal, sehingga layak dilakukan pengujian secara statistik. Dasar pengambilan keputusan bisa dilakukan berdasarkan 
Windayani, Khairil Anwar; Pengaruh Prilaku Belajar, Kecerdasan Emosional dan Pembahasan Hablumminnannas Terhadap Kepribadian Akademik Di Institut Agama Islam Tafaqquh Fiddin Dumai

probabilitas

(Asymtotic Significance).

2. Uji multikolineritas

Uji ini bertujuan untuk menguji apakah dalam model regresi ditemukan adanya korelasi yang tinggi atau sempurna antara variabel bebas atau tidak. Dengan demikian berarti semakin besar korelasi diantara sesama variabel independen, maka tingkat kesalahan dari koefisien regresi semakin besar yang mengakibatkan standar errornya semakin besar pula. Adapun Cara yang pendeteksian ada tidaknya multikoliniearitas adalah dengan menggunakan Variance Inflation Factors (VIF).

$$
V I F=\frac{1}{1-R_{i}^{2}}
$$

Dimana $\mathrm{Ri}^{2}$ adalah koefisien determinasi yang diperoleh dengan meregresikan salah satu variabel bebas $\mathrm{Xi}$ terhadap variabel bebas lainnya. Jika nilai VIF nya kurang dari 10 maka dalam data tidak terdapat multikolinieritas (Gujarati, 2004: 362).

3. Uji heteroskedastisitas

Bertujuan untuk menguji apakah dalam model regresi terjadi ketidaksamaan variance dari residual pengamatan satu ke pengamatan yang lain tetap. Jika variance dari residual satu pengamatan ke pengamatan yang lain tetap disebut sebagai homokeasitas dan jika berbeda disebut heteroskedatisitas atau tidak terjadi heteroskedatisitas. Carayang digunakan untuk mengetahui ada tidaknya heteroskaditisitas dalam suatu model regresi linier adalah dengan melihat grafik scatterplot atau nilai prediksi 292ariable terikat yaitu SRESID dengan residual error yaitu ZPRED. Jika tidak ada pola tertentu dan tidak menyebar diatas dan dibawah angka nol pada sumbu y, maka tidak terjadi heteroskedastisitas (Mariyanti, 2015)

4. Uji Signifikansi Simultan (Uji $\mathrm{F})$ Uji global disebut juga uji signifikansi serentak/simultan atau Uji F. Uji ini dimaksudkan untuk melihat kemampuan menyeluruh dari variabel bebas yaitu $\mathrm{X} 1, \mathrm{X} 2, \ldots . \mathrm{Xn}$, untuk dapat atau mampu menjelaskan tingkah laku atau keragaman variabel tidak bebas Y. Uji global juga dimaksudkan untuk mengetahui apakah semua variabel dependen memiliki koefisien regresi sama dengan nol.(Suharyadi dan Purwanto, 2004)

\section{Hasil Penelitian}

Uji normalitas yang dimaksud dalam asumsi klasik pendekatan OLS adalah (data) residual yang dibentuk model regresi linier terdistribusi normal, bukan variabel bebas ataupun variabel terikatnya. Pengujian terhadap residual terdistribusi normal dapat menggunakan Jarque-Bera Test. Hasil uji reliabilitas dapat dilihat pada Tabel 4.4. 
Tabel 4.4

Uji Jarque-Bera

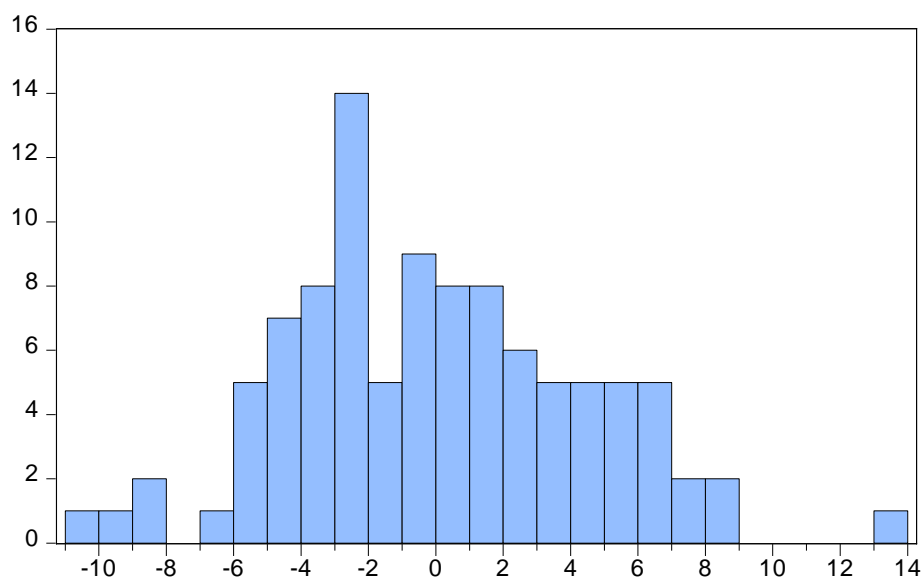

\begin{tabular}{|lr|}
\hline \multicolumn{2}{|l|}{ Series: Residuals } \\
Sample 1100 \\
Observations & 100 \\
Mean & $-1.01 \mathrm{e}-14$ \\
Median & -0.448267 \\
Maximum & 13.86168 \\
Minimum & -10.28020 \\
Std. Dev. & 4.410102 \\
Skewness & 0.295983 \\
Kurtosis & 3.034244 \\
& \\
Jarque-Bera & 1.464982 \\
Probability & 0.480710 \\
\hline
\end{tabular}

Sumber: Data olahan Eviews7

Berdasarkan tabel 4.4 Jarque-Bera Test Apabila Prob. Prob JB hitung lebih besar dari 0,05 maka dapat disimpulkan bahwa residual terdistribusi normal dan sebaliknya, apabila nilainya lebih kecil maka tidak cukup bukti untuk menyatakan bahwa residual terdistribusi normal. Nilai Prob. JB hitung sebesar 0,48 > 0,05 sehingga dapat disimpulkan bahwa residual terdistribusi normal yang artinya asumsi klasik tentang kenormalan telah dipenuhi Hasil Uji Multikolinearitas
Metode uji Multikolineralitas digunakan untuk mendeteksi ada atau tidaknya penyimpangan. Untuk itu maka dapat digunakan rumus Varian Inflation Factor (VIF) yang merupakan kebalikan dari toleransi. Asumsi multikolinieritas terpenuhi jika nilai VIF pada output SPSS dibawah 10 dan memiliki nilai positif. Karena VIF $=1 /$ Tolerance, maka asumsi bebas multikolinieritas juga dapat ditentukan jika nilai tolerance diatas 0,1 .

Tabel 4.5

Variance Inflation Factors

\begin{tabular}{cccc}
\hline \hline Variable & $\begin{array}{c}\text { Coefficient } \\
\text { Variance }\end{array}$ & $\begin{array}{c}\text { Uncentered } \\
\text { VIF }\end{array}$ & $\begin{array}{c}\text { Centered } \\
\text { VIF }\end{array}$ \\
\hline \hline X1 & 0.005605 & 251.6757 & 2.714921 \\
X2 & 0.000814 & 195.1177 & 1.971298 \\
X3 & 0.002974 & 237.8357 & 2.932012 \\
C & 23.44852 & 116.9107 & NA \\
\hline \hline
\end{tabular}

Sumber: Olahan Data Eviews7

Berdasarkan tabel 4.5 hasil perhitungan nilai tolerance juga menunjukkan tidak ada variabel independen yang memiliki tolerance kurang dari 0,10 . Hasil perhitungan nilai Variance Inflation Factor (VIF) juga menunjukkan hal yang sama tidak ada satupun variabel independen yang memiliki nilai VIF lebih dari 10 . Sehingga 
Windayani, Khairil Anwar; Pengaruh Prilaku Belajar, Kecerdasan Emosional dan Pembahasan Hablumminnannas Terhadap Kepribadian Akademik Di Institut Agama Islam Tafaqquh Fiddin Dumai

kesimpulannya bahwa variabel independen terbebas dari asumsi klasik multikolniearitas karena hasilnya lebih kecil dari 10.
a) Hasil Uji
Heteroskedastisitas
Hasil
Heteroskedastisitas
bertujuan bertujuan untuk

mengetahui ada aatu tidaknya penyimpangan asumsi klasik heteroskedastisitas yaitu adanya ketidaksamaan varian dari residual untuk semua pengamatan pada model regresi.

Tabel 4.6

Heteroskedasticity Test: Glejser

\begin{tabular}{llll}
\hline \hline F-statistic & 1.201920 & Prob. $\mathrm{F}(3,96)$ & $\overline{0.3133}$ \\
Obs ${ }^{\star}$ R-squared & 3.620031 & Prob. Chi-Square(3) & 0.3055 \\
Scaled explained SS & 3.212060 & Prob. Chi-Square(3) & 0.3601 \\
\hline \hline
\end{tabular}

Sumber: Data Olahan Eviews7

Dari table 4.6, Dengan menggunakan Uji Hetorokedastitas model Glejser, Keputusan terjadi atau tidaknya heteroskedastisitas pada model regresi linier adalah dengan melihat Nilai Prob. F-statistic ( $F$ hitung). Apabila nilai Prob. $F$ hitung lebih besar dari tingkat alpha 0,05 maka $\mathrm{H}_{0}$ diterima yang artinya tidak terjadi heteroskedastisitas, sedangkan apabila nilai Prob. F hitung lebih kecil dari dari tingkat alpha 0,05 maka $\mathrm{H}_{0}$ ditolak yang artinya terjadi heteroskedastisitas.suatu pola tertentu yang jelas, serta tersebar di atas dan di bawah angka nol pada sumbu Y. Jadi dapat disimpulkan bahwa model regresi dalam penelitian ini bebas dari heteroskedastisitas, dimana Prob $\mathrm{F}$ hitung $(0,313)>0,05$.

b) Hasil uji Linieritas

Linieritas merupakan asumsi awal yang seharusnya ada dalam model regresi linier. Uji linieritas dapat dengan mudah dilakukan pada regresi linier sederhana, yaitu membuat scatter diagram dari variabel bebas dan terikatnya. Apabila scatter diagram menunjukkan bentuk garis lurus maka dapat dikatakan bahwa asumsi linieritas terpenuhi. Untuk regresi linier berganda, pengujian terhadap linieritas dapat menggunakan Ramsey Reset Test.

Tabel 4.7

Ramsey RESET Test

\begin{tabular}{lccc}
\hline \hline & Value & Df & Probability \\
\cline { 2 - 4 } t-statistic & 0.731821 & 95 & 0.4661 \\
F-statistic & 0.535563 & $(1,95)$ & 0.4661 \\
Likelihood ratio & 0.562167 & 1 & 0.4534 \\
\hline \hline
\end{tabular}

Sumber: Data Olahan Eviews7

Apabila nilai Prob. $F$ hitung lebih besar dari tingkat alpha 0,05
(5\%) maka model regresi memenuhi asumsi linieritas dan sebaliknya, 
Al-Fikra: Jurnal IImiah Keislaman, Vol. 16, No. 2,Juli - Desember, 2017 (269 304 )

apabila nilai Prob. F hitung lebih kecil dari 0,05 maka dapat model tidak memenuhi asumsi linieritas. Nilai Prob. F hitung dapat dilihat pada baris F-statistic kolom Probability. Pada kasus ini nilainya 0,466 lebih besar dari 0,05 sehingga dapat disimpulkan bahwa model regresi telah memenuhi asumsi linieritas.

\section{A. Deskriptif Responden}

Penelitian ini menggunakan kuesioner sebagai instrumen yang terdiri dari 138 item pernyataan, yang terdiri dari 23 item pernyataan untuk variabel Prilaku Belajar, 64 item pernyataan untuk mengukur variabel kecerdasan emosional, 33 item pernyataan untuk mengukur variabel pemahaman hablumminannas dan 18 item pernyataan untuk mengukur variabel kepribadiaan akademik, dengan menggunakan skala likert dengan instrumen 5 kategori respon mulai dari sangat tidak setuju sampai dengan sangat setuju. Kuesioner yang diedarkan pada mahasiswa IAITF Dumai, berjumlah 165 eksemplar. Kuesioner yang terisi dengan baik berjumlah 100 eksemplar.

Karakteristik responden, merupakan gambaran tentang jenis kelamin dan program studi mahasiswa. Adapun karakteristik responden disajikan pada tabel 4.8.

Berdasarkan informasi yang disajikan dari Tabel 4.8 di atas, maka dapat dideskripsikan bahwa responden berdasarkan jenis kelamin didominasi oleh responden perempuan sebesar $74 \%$, mengindikasikan tingginya kuantitas mahasiswa dengan jenis kelamin perempuan di Institut Agama Islam Tafaqquh Fiddin Dumai

Tabel 4.8

Karakteristik Responden

\begin{tabular}{|c|c|c|c|}
\hline No & Karakteristik & $\begin{array}{r}\text { Jumlah } \\
\text { (orang) }\end{array}$ & Persentase \\
\hline \multirow[t]{3}{*}{1} & Jenis Kelamin & & \\
\hline & Laki-laki & 26 & $26 \%$ \\
\hline & Perempuan & 74 & $74 \%$ \\
\hline \multicolumn{2}{|r|}{ Jumlah } & 100 & $100 \%$ \\
\hline \multirow[t]{6}{*}{2} & Program Studi & & \\
\hline & Pendidikan Agama Islam & 64 & $64 \%$ \\
\hline & Ahwal al Syakhsiyyah & 8 & $8 \%$ \\
\hline & Muamalah & 6 & $6 \%$ \\
\hline & Ekonomi Syariah & 15 & $15 \%$ \\
\hline & Manajemen Pendidikan Islam & 7 & $7 \%$ \\
\hline \multicolumn{2}{|r|}{ Jumlah } & 100 & $100 \%$ \\
\hline
\end{tabular}


Windayani, Khairil Anwar; Pengaruh Prilaku Belajar, Kecerdasan Emosional dan Pembahasan Hablumminnannas Terhadap Kepribadian Akademik Di Institut Agama Islam Tafaqquh Fiddin Dumai

Tabel 4.11

Hasil Pengukuran Variabel

\begin{tabular}{|ll|r|r|r|r|}
\hline & \multicolumn{1}{|c|}{ JK } & N & Mean & $\begin{array}{c}\text { Std. } \\
\text { Deviation }\end{array}$ & $\begin{array}{c}\text { Std. Error } \\
\text { Mean }\end{array}$ \\
\hline P_Belajar & Lelaki & 26 & 94.04 & 5.758 & 1.129 \\
& Perempuan & 74 & 94.51 & 11.031 & 1.282 \\
Kc_Emosional & Lelaki & 26 & 223.81 & 20.205 & 3.963 \\
& Perempuan & 74 & 219.38 & 23.047 & 2.679 \\
Pm_Hablumminannas & Lelaki & 26 & 125.92 & 10.036 & 1.968 \\
& Perempuan & 74 & 125.84 & 15.374 & 1.787 \\
Kp_Akademik & Lelaki & 26 & 67.88 & 6.295 & 1.235 \\
& Perempuan & 74 & 66.58 & 7.540 & .876 \\
\hline
\end{tabular}

Sumber: Data Olahan SPSS21

Tabel 4.12

Uji Independen Sampel

\begin{tabular}{|c|c|c|c|c|}
\hline & \multicolumn{3}{|c|}{ t-test for Equality of Means } \\
\hline & & df & $\begin{array}{l}\text { Sig. }(2- \\
\text { tailed) }\end{array}$ & $\begin{array}{c}\text { Mean } \\
\text { Difference }\end{array}$ \\
\hline & $\begin{array}{ll}\text { Equal } & \text { variances }\end{array}$ & 98 & .835 & -.475 \\
\hline P_Belajar & $\begin{array}{l}\text { Equal variances not } \\
\text { assumed }\end{array}$ & 83.492 & .782 & -.475 \\
\hline Ka 5 magiand & $\begin{array}{ll}\text { Equal } & \text { variances } \\
\text { assumed } & \end{array}$ & 98 & .387 & 4.429 \\
\hline Kc_Emosional & $\begin{array}{l}\text { Equal variances not } \\
\text { assumed }\end{array}$ & 49.537 & .359 & 4.429 \\
\hline & $\begin{array}{ll}\text { Equal } & \text { variances } \\
\text { assumed } & \end{array}$ & 98 & .979 & .085 \\
\hline Pm_Hablumminannas & $\begin{array}{l}\text { Equal variances not } \\
\text { assumed }\end{array}$ & 67.507 & .975 & .085 \\
\hline Kn Alendomil & $\begin{array}{ll}\text { Equal } & \text { variances } \\
\text { assumed } & \end{array}$ & 98 & .432 & 1.304 \\
\hline n_p_raquentin & $\begin{array}{l}\text { Equal variances not } \\
\text { assumed }\end{array}$ & 52.028 & .393 & 1.304 \\
\hline
\end{tabular}

Berdasarkan program studi mahasiswa, menunjukkan bahwa mahasiswa di Institut Agama Islam Tafaqquh Fiddin Dumai, didominasi memilih program studi Pendidikan Agama Islam sebesar $64 \%$. Ini mengindikasikan tingginya tingkat kuantitas mahasiswa Program Studi Pendidikan Agama Islam di Institut Agama Islam Tafaqquh Fiddin Dumai.

i. Deskriptif Variabel

Salah satu teknik pengumpulan data pada penelitian 
Al-Fikra: Jurnal IImiah Keislaman, Vol. 16, No. 2,Juli - Desember, 2017 (269 304 )

ini adalah menggunakan kuisioner yang didistribusikan kepada seluruh mahasiswa. Kuisioner ini digunakan untuk mengukur tiga variabel bebas yaitu variabel prilaku belajar, kecerdasan emosional dan Berdasarkan Tabel 4.11 dapat dilihat, bahwa berdasarkan jenis kelamin rata-rata masingmasing dari kelima variabel (prilaku belajar, kecerdasan emosional, pemahaman hablumminannas dan kepribadian akademik) yang diukur terlihat ada perbedaan, dengan melakukan uji t seperti pada table 4.12 , ternyata nilai taraf sig. kelima pemahaman hablumminannas, serta satu variabel terikat yaitu kepribadiaan akademik Hasil penelitian dapat diketahui jawaban responden atas kuesioner tersebut dan tersaji dalam Tabel 4.11.

variabel tersebut lebih besar dari 0,05 , ini menyatakan bahwa perbedaan nilai dari prilaku belajar, kecerdasaan emosional, pemahaman hablumminannas dan kepribadian akademik mahasiswa di Institut Agama Islam Tafaqquh Fiddin Dumai berdasarkan jenis kelamin memiliki perbedaan yang signifikan.

Tabel 4.13

Hasil Pengukuran Variabel

\begin{tabular}{|c|c|c|c|c|c|c|}
\hline & \multirow[t]{2}{*}{$\mathrm{N}$} & \multirow[t]{2}{*}{ Mean } & \multirow[t]{2}{*}{$\begin{array}{c}\text { Std. } \\
\text { Deviation }\end{array}$} & \multirow[t]{2}{*}{$\begin{array}{l}\text { Std. } \\
\text { Error }\end{array}$} & $\begin{array}{c}95 \% \\
\text { Confidence } \\
\text { Interval for } \\
\text { Mean } \\
\end{array}$ \\
\hline & & & & & & $\begin{array}{l}\text { Lower } \\
\text { Bound }\end{array}$ \\
\hline \multirow{7}{*}{ P_Belajar } & PAl & 64 & 94.88 & 8.520 & 1.065 & 92.75 \\
\hline & AS & 8 & 95.75 & 8.988 & 3.178 & 88.24 \\
\hline & MUAMALAH & 6 & 95.17 & 7.731 & 3.156 & 87.05 \\
\hline & ES & 15 & 95.07 & 8.980 & 2.319 & 90.09 \\
\hline & MPI & 7 & 86.29 & 21.014 & 7.942 & 66.85 \\
\hline & Total & 100 & 94.39 & 9.907 & .991 & 92.42 \\
\hline & PAl & 64 & 221.89 & 21.601 & 2.700 & 216.49 \\
\hline & AS & 8 & 224.00 & 19.243 & 6.803 & 207.91 \\
\hline \multirow{5}{*}{ Kc_Emosional } & MUAMALAH & 6 & 222.50 & 17.649 & 7.205 & 203.98 \\
\hline & ES & 15 & 218.53 & 17.233 & 4.450 & 208.99 \\
\hline & MPI & 7 & 206.71 & 40.869 & 15.447 & 168.92 \\
\hline & Total & 100 & 220.53 & 22.329 & 2.233 & 216.10 \\
\hline & PAI & 64 & 126.58 & 12.899 & 1.612 & 123.36 \\
\hline \multirow{4}{*}{ Pm_Hablumminannas } & AS & 8 & 126.75 & 9.036 & 3.195 & 119.20 \\
\hline & MUAMALAH & 6 & 125.33 & 6.532 & 2.667 & 118.48 \\
\hline & ES & 15 & 127.67 & 11.095 & 2.865 & 121.52 \\
\hline & MPI & 7 & 114.86 & 31.211 & 11.797 & 85.99 \\
\hline \multirow{5}{*}{ Kp_Akademik } & Total & 100 & 125.86 & 14.132 & 1.413 & 123.06 \\
\hline & PAI & 64 & 67.64 & 6.790 & .849 & 65.94 \\
\hline & AS & 8 & 66.00 & 3.742 & 1.323 & 62.87 \\
\hline & MUAMALAH & 6 & 69.00 & 8.319 & 3.396 & 60.27 \\
\hline & ES & 15 & 67.27 & 6.984 & 1.803 & 63.40 \\
\hline
\end{tabular}


Windayani, Khairil Anwar; Pengaruh Prilaku Belajar, Kecerdasan Emosional dan Pembahasan Hablumminnannas Terhadap Kepribadian Akademik Di Institut Agama Islam Tafaqquh Fiddin Dumai

\begin{tabular}{|l|r|r|r|r|r|} 
MPI & 7 & 58.86 & 10.156 & 3.839 & 49.46 \\
Total & 100 & 66.92 & 7.229 & .723 & 65.49 \\
\hline
\end{tabular}

Sumber: Data Olahan SPSS21

Berdasarkan Tabel 4.13 dapat kepribadian akademik berdasarkan dilihat, bahwa rata-rata nilai prilaku variabel prodi memiliki nilai yang belajar, kecerdasan emosional, berbeda. pemahaman hablumminannas dan

Tabel 4.14

Uji Homogenitas Varian

\begin{tabular}{|l|r|r|r|r|}
\hline & Levene Statistic & df1 & df2 & Sig. \\
\hline P_Belajar & 2.058 & 4 & 95 & .092 \\
Kc_Emosional & .982 & 4 & 95 & .421 \\
Pm_Hablumminannas & 2.391 & 4 & 95 & .056 \\
Kp_Akademik & .670 & 4 & 95 & .614 \\
\hline
\end{tabular}

Sumber: Data Olahan SPSS21
Berdasarkan table 4.14 uji homogenitas varian dari sampel yang ditetapkan, ternyata nilai sig. dari kelima variabel (kecerdasan emosional, prilaku belajar,

\begin{abstract}
kepribadian akademik) berdasarkan variabel prodi lebih besar dari 0,05, ini berarti bahwa data dari kelima variabel tersebut memiliki varian yang sama.
\end{abstract} pemahaman hablumminannas dan

Tabel 4.15

Analisis Varian

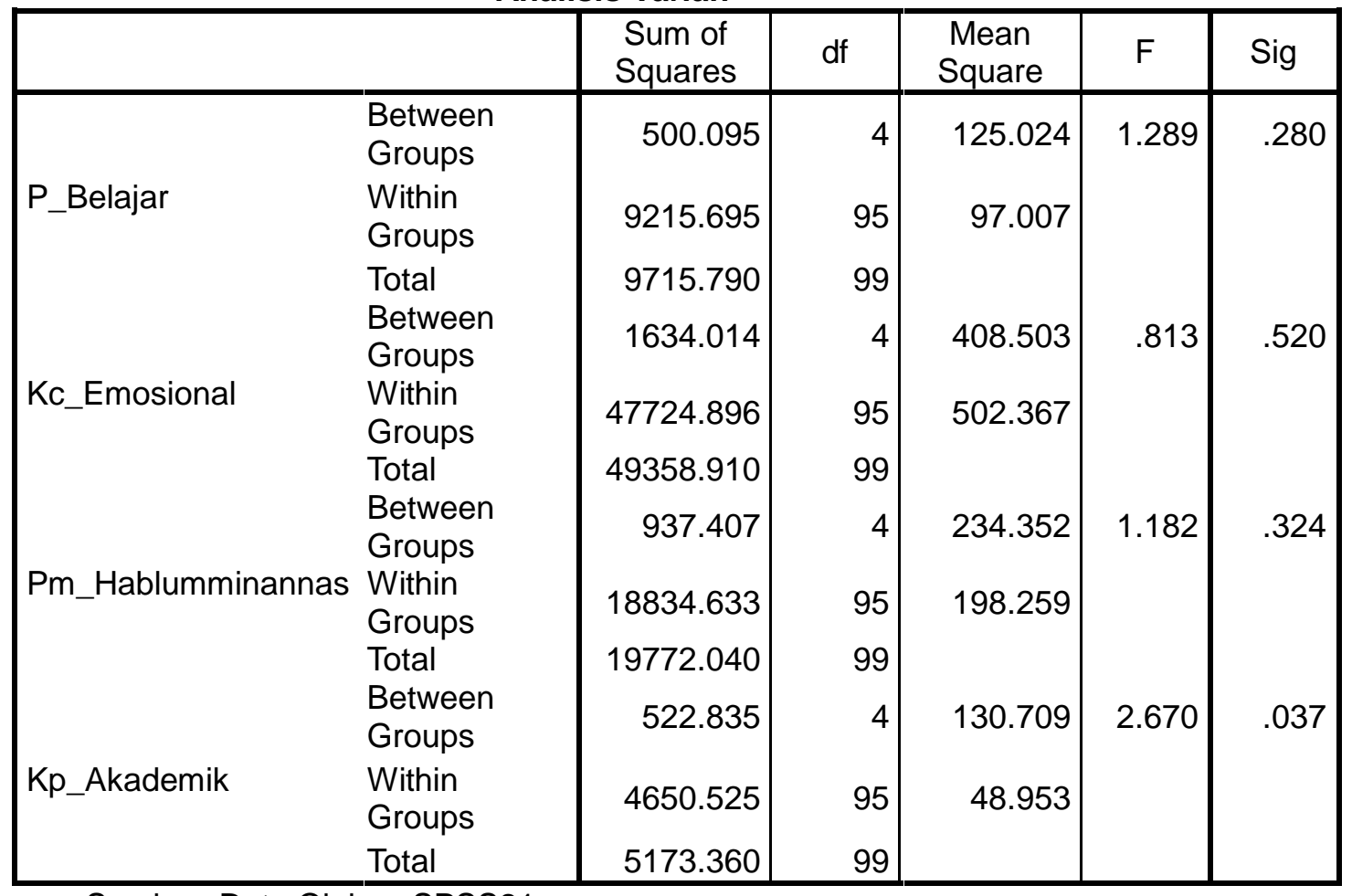

Sumber: Data Olahan SPSS21 
Al-Fikra: Jurnal IImiah Keislaman, Vol. 16, No. 2,Juli - Desember, 2017 (269 304 )

Berdasarkan tabel 4.15 dapat dilihat, bahwa variabel kepribadian akademik memiliki nilai sig. 0,037< 0,05 , berarti berdasarkan variabel program studi variabel kepribadian akademik memiliki perbedaan nilai rata-rata yang signifikan sedangkan variabel kecerdasan emosional, pemahaman hablumminannas dan prilaku belajar memiliki nilai sig. lebih besar dari 0,05 , berarti variabel ini tidak memiliki perbedaan yang signifikan.

Sumber: Data Olahan SPSS21. Setelah mengetahui bahwa pengukuran berdasarkan variabel prodi yang memiliki perbedaan nilai rata-rata yang signifikan adalah variabel kepribadian akademik mahasiswa. Untuk mengetahui prodi mana yang memiliki perbedaan yang signifikan dari kelima prodi yang diukur, berdasarkan uji multi komparatif pada table 4.16 ditemukan bahwa prodi PAI yang memiliki nilai perbedaan kepribadian akademik yang sangat berarti.

\section{Hasil Koefisien Determinasi}

Koefesien determinasi pada regresi linear mengukur kemampuan semua variabel bebas dalam menjelaskan varians dari variabel terikatnya. Secara sederhana koefisien determinasi dihitung dengan mengkuadratkan Koefesien Korelasi (R). Hasil koefesien determinasi dapat dilihat dalam tabel 4.18:

Tabel 4.17

Hasil Uji Koefisien Determinasi

\begin{tabular}{lrll}
\hline \hline R-squared & 0.627814 & Mean dependent var & 66.92000 \\
Adjusted R-squared & 0.616183 & S.D. dependent var & 7.228842 \\
S.E. of regression & 4.478480 & Akaike info criterion & 5.875622 \\
Sum squared resid & 1925.451 & Schwarz criterion & 5.979829 \\
Log likelihood & -289.7811 & Hannan-Quinn criter. & 5.917797 \\
F-statistic & 53.97858 & Durbin-Watson stat & 1.712234 \\
Prob(F-statistic) & 0.000000 & & \\
\hline \hline
\end{tabular}

Sumber: Data Olahan Eviews7

Tabel 4.17 menunjukkan

koefesien $R$ Square. $R$ Square

menjelaskan seberapa variasi $y$

yang disebabkan oleh $\mathrm{x}$, dari tabel

koefesien determinasi dapat dilihat

bahwa angka koefesien korelasi (R)

sebesar 0,6278\%. Hal ini berarti

hubungan antara variabel

independen dengan variabel

dependen 62,78\%. Dari angka tersebut dapat diambil keputusan bahwa hubungan antara variabel independen dengan variabel dependen sangat kuat. Berdasarkan tabel hasil nilai adjusted $\mathrm{R}$ square (R2) adalah sebesar 0,6278\%. Hasil perhitungan statistik ini berarti kemampuan variabel dalam menerangkan variasinya perubahan variabel dependen $62,78 \%$, sedangkan sisanya sebesar $37,22 \%$ (100-62,78\%) dipengaruhi oleh faktor-faktor lain diluar model regresi yang dianalisis.

\section{Hasil Uji Hipotesis}

Persamaan regresi dapat dilihat dari tabel hasil uji berdasarkan output Eviews7 dari ketiga variabel independen yaitu etika prilaku belajar, kecerdasan emosional dan pemahaman hablumminannas terhadap variabel dependen kepribadiaan akademik sebagai berikut: 
Windayani, Khairil Anwar; Pengaruh Prilaku Belajar, Kecerdasan Emosional dan Pembahasan Hablumminnannas Terhadap Kepribadian Akademik Di Institut Agama Islam Tafaqquh Fiddin Dumai

Dependent Variable: $Y$

Tabel 4.18

Hasil Uji Coefficients

\begin{tabular}{ccccc}
\hline \hline Variable & Coefficient & Std. Error & t-Statistic & Prob. \\
\hline \hline X1 & 0.161524 & 0.074863 & 2.157580 & 0.0335 \\
X2 & 0.079356 & 0.028539 & 2.780626 & 0.0065 \\
X3 & 0.211798 & 0.054537 & 3.883594 & 0.0002 \\
C & 7.710089 & 4.842367 & 1.592215 & 0.1146 \\
\hline
\end{tabular}

Sumber: Data olahan Eviews7

Analisis regresi linier berganda digunakan meramalkan bagaimana keadaan (naik turunnya) variabel dependen, bila dua atau lebih variabel independen sebagai faktor prediktor dimanipulasi (dinaik turunkan) nilainya. Jadi analisis regresi ganda akan dilakukan jika jumlah variabel independennya minimal dua. Uji- $F$ digunakan untuk menguji pengaruh variabel independen secara bersama-sama terhadap variabel dependen dari suatu persamaan regresi.
Pengambilan keputusan didasarkan pada nilai probabilitas yang didapatkan dari hasil pengolahan data melaui program Eviews7 Statistik Parametrik sebagai berikut:

1. Jika probabilitas $>0,05$ maka $\mathrm{H}_{0}$ diterima

2. Jika probabilitas $<0,05$ maka $\mathrm{H}_{0}$ ditolak

Nilai probabilitas dari uji-f dapat dilihat pada hasil pengolahan dari program Eviews7 pada tabel 4.13 baris Prob (F-hitung). Hasil uji $F$ dapat dilihat dalam tabel dibawah ini:

Tabel 4.19

Hasil Uji Parsial

\begin{tabular}{|l|r|r|r|}
\hline \multirow{2}{*}{\multicolumn{1}{|c|}{ Independen Variabel }} & \multicolumn{3}{|c|}{ Kepribadian Akademik } \\
\cline { 2 - 4 } & \multicolumn{1}{c|}{$\mathrm{B}$} & $\mathrm{t}$ & $\mathrm{P}$ \\
\hline Perilaku Belajar & 0.16 & 2.15 & 0.0035 \\
Kecerdasan Emosional & 0.07 & 2.78 & 0.0065 \\
Pemahaman & & & \\
Hablumminnannas & 0.21 & 3.88 & 0.0002 \\
\hline R-squared $=0.63$ (63\%) dan $\mathrm{F}=53.97, \mathrm{P}<0.05$ \\
\hline
\end{tabular}

Berdasarkan tabel 4.19 di atas dengan menggunakan uji multiple regression secara simultan adanya pengaruh Perilaku belajar, kecerdasan emosional dan pemahaman hablumminnannas terhadap kepribadian akademik dimana $\mathrm{F}=53.97$ dengan $\mathrm{P}<0.05$, adapun hasil pengaruh perilaku belajar, kecerdasan emosional dan pemahaman hablumminnannas terhadap kepribadian akademik sebesar $63 \%$. Dilihat secara parsial, Variabel Independen yang paling tinggi pengaruhnya terhadap Kepribadian Akademik adalah Pemahaman Hablumminnannas, kemudian kecerdasan emosional dan yang paling rendah perilaku belajar. Dengan demikian hipotesis 
yang menyatakan adanya pengaruh pengaruh perilaku belajar, kecerdasan emosional dan pemahaman hablumminnannas terhadap kepribadian akademik diterima.

\section{a) Uji Signifikansi Individual} (Uji parsial t)

Uji $t$ digunakan untuk menguji pengaruh variabel independen prilaku belajar, kecerdasan emosional, pemahaman hablumminannas secaraparsial berpaengaruh terhadap variabel dependen kepribadian akademik. Pengambilan keputusan uji hipotesis secara parsial juga didasarkan pada nilai probabilitas yang didapatkan dari hasil pengolahan data melalui program Eviews7adalah sebagai berikut:

1. Jika probabilitas $>0,05$ maka $\mathrm{H}_{0}$ diterima

2. Jika probabilitas $<0,05$ maka $\mathrm{H}_{0}$ ditolak

Nilai probabilitas dapat dilihat pada tabel 4.20 kolom Prob (tstatistik)dengan menggunakan Eviews7.

Berdasarkan tabel 4.19 diatas, maka hasil regresi berganda dapat menganalisis pengaruh dari masing-masing variabel prilaku belajar, kecerdasan emosional, pemahaman hablumminannas terhadap kepribadian akademik dapat dilihat dari arah tanda dan tingkat signifikan (probabilitas). Variabel $\quad\left(X_{1}, X_{2}, X_{3}\right)$ semuanya mempunyai arah yang positif danberpengaruh signifikan terhadap kinerja karyawan karena nilai signifikannya lebih kecil dari 0,05.

1. Pengaruh prilaku belajar terhadap kepribadian akademik, dari hasil penelitian diperoleh koefesien transformasi regresi untuk variabel $X_{1}$ sebesar 0,162 yang berarti berpengaruh secara positif terhadap kepribadian akademik, nilai signifikasi yang dimiliki sebesar 0,033 dimana nilai ini signifikan lebih kecil dari 0,05. Karena tingkat signifikansinya kurang dari $0,05 \%$, maka dalam hal ini pengaruh prilaku belajar terhadap kepribadian akademik sangat signifikan.

2. Pengaruh kecerdasan emosional terhadap kepribadian akademik, dari hasil penelitian diperoleh koefesien transformasi regresi untuk variabel $\mathrm{X}_{2}$ sebesar 0,079 yang berarti berpengaruh secara positif terhadap kepribadian akademik, nilai signifikasi yang dimiliki sebesar 0,006 dimana nilai ini signifikan lebih kecil dari 0,05. Karena tingkat signifikansinya kurang dari 0,05 , maka dalam hal ini pengeruh kecerdasan emosional terhadap kepribadian akademik sangat signifikan.

3. Pengaruh pemahaman hablumminannas terhadap kepribadian akademik, dari hasil penelitian diperoleh koefesien transformasi regresi untuk variabel $X_{3}$ sebesar 0,212 yang berarti berpengaruh secara positif terhadap kepribadian akademik, nilai signifikasi yang dimiliki sebesar 0,000 dimana nilai ini lebih kecil dari 0,05. Karena tingkat signifikansinya lebih kecil dari 0,05, maka dalam hal ini pengaruh pemahaman hablumminannas terhadap kepribadian akademik adalah signifikan.

Setelah dilakukan pengujian secara simultan dan parsial maka model yang layak digunakan sebagai predictor adalah:

Kp_Akademik $=7,710+0,162 X_{1}+$ $0,079 X_{2}+0,212 X_{3}+e$ 
Windayani, Khairil Anwar; Pengaruh Prilaku Belajar, Kecerdasan Emosional dan Pembahasan Hablumminnannas Terhadap Kepribadian Akademik Di Institut Agama Islam Tafaqquh Fiddin Dumai

Dari model di atas dapat dijelaskan bahwa kepribadiaan akademik mahasiswa sangat ditentukan oleh ketiga variabel bebas yaitu: prilaku belajar, kecerdasan emosional dan pemahaman hablumminannas yang berkontribusi sebesar $62,78 \%$. Sekiranya ketiga variabel tersebut tetap atau tidak ada sama sekali maka kepribadian akademik mahasiswa tidak terbentuk sama sekali.

\section{Pembahasan}

Hasil penelitian Pengaruh prilaku belajar terhadap kepribadian akademik, dari hasil penelitian diperoleh koefesien transformasi regresi untuk variabel $\mathrm{X}_{1}$ sebesar 0,162 yang berarti berpengaruh secara positif terhadap kepribadian akademik, nilai signifikasi yang dimiliki sebesar 0,033 dimana nilai ini signifikan lebih kecil dari 0,05. Karena tingkat signifikansinya kurang dari 0,05, maka dalam hal ini pengaruh prilaku belajar terhadap kepribadian akademik sangat signifikan. Hasil penelitian Pengaruh kecerdasan emosional terhadap kepribadian akademik, dari hasil penelitian diperoleh koefesien transformasi regresi untuk variabel $\mathrm{X}_{2}$ sebesar 0,079 yang berarti berpengaruh secara positif terhadap kepribadian akademik, nilai signifikasi yang dimiliki sebesar 0,006 dimana nilai ini signifikan lebih kecil dari 0,05 . Karena tingkat signifikansinya kurang dari 0,05, maka dalam hal ini pengeruh kecerdasan emosional terhadap kepribadian akademik sangat signifikan

Hasil penelitian Pengaruh pemahaman hablumminannas terhadap kepribadian akademik, dari hasil penelitian diperoleh koefesien transformasi regresi untuk variabel $\mathrm{X}_{3}$ sebesar 0,212 yang berarti berpengaruh secara positif terhadap kepribadian akademik, nilai signifikasi yang dimiliki sebesar 0,000 dimana nilai ini lebih kecil dari 0,05 . Karena tingkat signifikansinya lebih kecil dari 0,05, maka dalam hal ini pengaruh pemahaman hablumminannas terhadap kepribadian akademik adalah signifikan.

\section{Kesimpulan}

Terdapat Pengaruh yang positif dan signifikan antara Perilaku Belajar, Kecerdasan Emosional, dan Pemahaman Hablumminnannas secara serentak terhadap Kepribadian Akademik Mahasiswa di Institut Tafaqquh Fiddin Dumai. Berdasarkan Jenis Kelamin pengaruh perilaku belajar, kecerdasan emosional, pemahaman hablumminnannas dan kepribadian akademik terdapat pengaruh yang signifikan, sedangkan perbedaan berdasarkan program studi yaitu Pendidikan Agama Islam, baik berdasarkan perilaku belajar, kecerdasan emosional, pemahaman hablumminannas dan kepribadian akademik, berdasarkan program studi mahasiswa program studi pendidikan agama islam yang lebih tinggi perbedaanya.

\section{DAFTAR KEPUSTAKAAN}

\begin{tabular}{rrr} 
Ahmadi, & \multicolumn{1}{c}{ Abu, } & 1991.Sosiologi \\
& Pendidikan, & Jakarta: \\
Rajawali. & \\
Arisandi, & Deni, 2016. & $\begin{array}{r}\text { Pengertian } \\
\text { dalam }\end{array}$ \\
Perilaku & http://arisandi.com/pengert \\
& $\begin{aligned} \text { ian perilaku. ( diunduh } \\
\text { pada hari sabtu, 27 } 27\end{aligned}$
\end{tabular}


Al-Fikra: Jurnal IImiah Keislaman, Vol. 16, No. 2,Juli - Desember, 2017 (269 304)

februari 2016 pukul 11.45 WIB).

Abin, S. Makmun, 2007. Psikologi Kependidikan Perangkat Sistem Pengajaran Modul, Bandung: PT. Remaja Rosdakarya.

Arifin, M, 1994. Ilmu Pendidikan Islam, Jakarta: Bumi Aksara.

Anonim, 2012. Dimensi-dimensi kecerdasan emosional, (diakses dari http://www.psychologyman ia.com pada tanggal 17 September 2017).

B.E, Sijabat, 2012. Membesarkan Anak dengan Kreatif, Yogyakarta:Penerbit

Dimyati dan Mudjiono, 1999. Belajar dan Pembelajaran, Jakarta: PT. Rineka Cipta.

Djarot Sensa, Muhammad, 2005.Kecerdasan-

kecerdasan Bentukan Alquran, Yogyakarta: Penerbit Hikmah.

Departemen Agama RI, Alquran dan Terjemahannya.

Dahlan, MD.1990. Konsep Manusia Berkualitas Yang Dipersepsi dari Alquran, Al-Hadis dan Qoul Ulama, Yogyakarta: Seminar.

Ginanjar Agustian Ary,2007. ESQ.Jakarta: Arga Publishing.

Hidayat, $\quad$ Komaruddin, 2006. Psikologi Beragama Menjadikan Nyaman Santun dan Hikmat. Jakarta: PT. Mizan Publika.

IAIN Syarif Hidayatullah, 1992. Ensiklopedi Islam Indonesia, Jakarta: Jambangan.

Hamalik, Omar, 1983. Kurikulum dan Pembelajaran, Jakarta: Bumi Aksara.
Shihab, M. Quraish,2001. Menyingkap Tabir lahi: AlAsma al-Husna dalam perspektif Al-Quran. Jakarta: Lentera Hati.

Najati, Usman, 1985. Alquran dan IImu Jiwa. Bandung: Pustaka.

Syah, Muhibbin, 2006. Psikologi Belajar, Jakarta: PT. Raja Grafisindo Perkasa.

Thimas, E. Odea, 1996.Sosiologi Agama Suatu Pengenalan Awal, Jakarta: Raja Grafisindo Persada.

Marhamah, Lc, MA, 2009. Kuliah Ibadah dan Syahadah, http://marhamahsaleh.

Wordpress.com.

Madjid, Nur Cholis, 2009. Kontekstualisasi Doktrin Islam dalam Sejarah, Jakarta: Media Mahardika Vol. 1 No. 14, Surabaya: STIE Mahardika.

Ginanjar,

Agustian,2008. Rahasia Sukses Membangun Kecerdasan Emosi dan Spritual. Jakarta: Arga.

Plus, A.Partanto,1994. Kamus IImiah Populer,Surabaya:Arkolo.

Prayitno. 2009. Dasar Teori dan Praksis Pendidikan. Jakarta : PT Grasindo.

M.Munandar, Soelaeman, 2008. IImu Sosial Dasar Teori dan Konsep IImu Sosial, Bandung:Refika Aditama.

Mudrika, Nafis. 2011. Membaca Kepribadian

Menggunakan Tes MBTI(Meyer Bigs Type Indicator).(http://www.nafis mudrika.wordpress.com). Diakses 19 September 2017.

Risharliea, Tifanie.2011. Kajian Empiris Atas perilaku belajar, kecerdasan 
Windayani, Khairil Anwar; Pengaruh Prilaku Belajar, Kecerdasan Emosional dan Pembahasan Hablumminnannas Terhadap Kepribadian Akademik Di Institut Agama Islam Tafaqquh Fiddin Dumai

\begin{tabular}{|c|c|c|c|}
\hline $\begin{array}{l}\text { Emosional } \\
\text { Kecerdasan }\end{array}$ & $\begin{array}{r}\text { dan } \\
\text { Spiritual }\end{array}$ & Sukirin, & $\begin{array}{cc}1981 . & \text { Pokok-pokok } \\
\text { Psikologi } & \text { Pendidikan, }\end{array}$ \\
\hline dalam $\quad \mathrm{N}$ & mpengaruhi & & Yogyakarta: FIP-IKIP. \\
\hline Stress Kulia & Mahasiswa & Sunarto, & $\mathrm{H}$ dan B.Agung Hartono. \\
\hline $\begin{array}{l}\text { Kuntansi. } \\
\text { Jogjakarta: } \\
\text { Ekonomi, }\end{array}$ & $\begin{array}{r}\text { Skripsi } \\
\text { Fakultas } \\
\text { Universitas }\end{array}$ & & $\begin{array}{l}\text { 2008. Perkembangan } \\
\text { Peserta Didik. Jakarta } \\
\text { Rineka Cipta. }\end{array}$ \\
\hline
\end{tabular}

Sugiyono, 2011. Metode Penelitian Pendidikan ( Pendekatan Kuantitatif, Kualitatif dan R\&D), Bandung: Alfabeta.

Shobikin Amin, 2015.Pengaruh Kepribadian, Sikap dan Persepsi Terhadap Perilaku Kewirausahawan Pelaku Usaha Industri Kecil Kerajinan Tangan dan Handycraft di Kabupaten Lamongan. Jurnal Ali, H.Muhammad,1996. Guru dalam Proses

Mengajar,Bandung: Sinar Baru Algesindo.

Walgito, 1987. Psikologi Sosial (Suatu Pengantar), Yogyakarta: Yayasan Penerbit Fakultas Psikologi.

Winarti, Septi.2012. Faktor-Faktor Yang Mempengaruhi Kecerdasan Emosi (diakses darihttp://www.blogger.co m pada tanggal 19 